Article

\title{
Integrating the Sustainable Development Goals in Building Projects
}

\author{
Sherif Goubran ${ }^{1, *}$, Carmela Cucuzzella ${ }^{2}$ \\ 1 Individualized (INDI) Program, Concordia University, Montreal, H3G 1M8, \\ Canada \\ 2 Design and Computation Arts, Concordia University, Montreal, H3G 1M8, \\ Canada \\ * Correspondence: Sherif Goubran, Email: Sherif.goubran@mail.concordia.ca.
}

\begin{abstract}
Building designers are struggling to deeply integrate the 2030 Agenda and its Sustainable Development Goals (SDGs) in projects. The review of the literature revealed that the available research is focused on linking the current practices, including sustainable building practices, with the SDGs. This has, in turn, limited the development of novel approaches as well as new building design methodologies that specifically aim at attaining the agenda's targets. To help building design teams achieve the meaningful integration of the agenda's five Ps, this paper proposes two analytical mapping tools which can be used during the integrated design process to track the integration of SDGs in the building projects, and to analyze the building design approaches and visions in reference to the topics of the goals. The research uses a case study for an energy-positive building in Quebec to test the proposed tools. The analysis focuses on the integration of 8 of 17 SDGs, discusses the specific building features which were used to achieve this integration, and analyzes the team's design visions regarding the goals. The results reveal that in the case studied, the integration of the 8 SDGs moves beyond the current standards by mostly applying design approaches which are future-driven and focused on products and technologies. This research provides important practical tools that can inform building practices in the private and the public sector and contributes to the theory and practice of sustainable building design. It also supports the current effort towards the implementation and localization of the SDGs.
\end{abstract}

\section{Gopen Access}

Received: 28 June 2019

Accepted: 28 August 2019

Published: 30 August 2019

Copyright $(2019$ by the author(s). Licensee Hapres, London, United Kingdom. This is an open access article distributed under the terms and conditions of Creative Commons Attribution 4.0 International License.
KEYWORDS: Sustainable Development Goals; integrated design; design for sustainability; sustainable building practice

\section{INTRODUCTION}

With more than 100 definitions for sustainability and 600 assessment methods available in the literature, design teams are facing uncertainties regarding the criteria and definition to adopt in sustainable building projects [1,2]. In the last 10 years, researchers focusing on sustainability in 
the built environment have consistently concluded that existing standards and tools are largely focused on the environmental dimension of sustainability [3-6]. Also, they highlighted that the available standards are commonly lacking indicators regarding the contextual, social, cultural and economic aspects of buildings [1,2,7,8]. Although there have been many attempts to establish new frameworks that integrate sustainability more comprehensively in buildings and the built environment, their wide adoption has been rather limited [2,9,10]. Today, international sustainable development agendas are gaining more attention beyond the public sector and are being increasingly integrated into private organizations and local practices [11,12].

The approval of the 2030 Agenda in 2015 marked a global milestone in the field of sustainability and sustainable development [13-15]. The agenda, including its Sustainable Development Goals (SDGs) and their targets, established a clear expansive framework for development which dedicates equal attention to the environmental, social and economic pillars of sustainability [16]. Moreover, the agenda's targets were strategically structured around five key themes: people, planet, prosperity, peace and partnership_commonly known as the five Ps [17]. The 2030 Agenda offers a stable and global definition for sustainability over the next 10 years which is accompanied by global, notation and local commitments $[11,15,18,19]$. This stability could benefit the construction sector, especially building designers, in overcoming some of the current limitations and assist in the sector's transition beyond its current ecological and energy performance focus $[11,20,21]$.

Achieving meaningful integration of the five Ps in building projects requires stepping back from the existing quantitative criteria for assessment, to consider the broader potential contribution of buildings to the SDGs and their targets. It also requires exploring the means to translate the global focus of the agenda to the local and project-specific level [12,22]. Although there has been a number of frameworks proposed for achieving the SDGs, they remain mostly conceptual in nature and are not adapted to specific needs of construction and building projects [22]. Available building-related research is aimed at intersecting individual credits or credit categories from dominant certification systems with the SDGs and estimating how they nominally contribute to the Agenda [23,24]. However, and to the best of the researchers' knowledge, no publications have attempted to propose frameworks that aim at facilitating and evaluating the integration of the SDGs in construction projects. Additionally, the authors were not aware of any research that aims to analyze design approaches on the topics of the SDGs in building projects.

This research aims to address these gaps by proposing two analytical maps that can be used by building design teams during the integrated design process (IDP)[25,26]. The tools are specifically developed to aid designers to understand and integrate the SDGs in building projects as well as to analyze the design approaches used in such integration. The paper 
starts by presenting a review of the relevant literature regarding the 2030 Agenda, and an overview of some of the current debates regarding sustainability in the built environment as well as its integration and design approaches. The methodology section of the paper presents the two maps and the theoretical frameworks used for their development. Additionally, the paper presents a list of building design questions which are based on the 17 SDGs along with the proposed method of application of the tools in real building projects. To illustrate and test the applicability of the proposed maps and analysis process, a case study for the design on an energy positive and low-carbon building in Quebec (Canada) is used. The methods section of the paper details the specific research tools that were used to apply the proposed methodology to the case study selected. The results section of the paper presents the outcome of the analysis conducted for the case. Since the authors were part of the integrated design team for this project, the paper also synthesizes the observations made during the design process. Finally, the discussion and conclusion sections present some of the broader implications of this research and propose some key directions for future research.

\section{REVIEW OF LITERATURE}

\section{Sustainability in the Built Environment}

Sustainability is often understood to be the resultant of the balanced intersection between the social, economic, and environmental dimensions. Scholars have also proposed to include the cultural, institutional, political as well as ethical dimensions as core pillars to sustainable design [1,27]. Since the rise of environmental design in the 1960s, the integration of the philosophy of sustainability in building and construction projects has led to the emergence of many doctrines around the topic [28]. As suggested by Zuo and Zhao [29], the current debates surrounding sustainability in the built environment can be categorized broadly around three key questions: (1) why sustainable buildings? (2) what is a sustainable building? and (3) how to achieve sustainability in buildings? Across all these debates, two key polarities can be consistently observed: (A) functionalist approaches which are regulatory in nature (i.e., aiming to establish sustainability in the built environment as a pragmatic field guided by quantitative standards), and (B) humanist approaches which are radical in nature (i.e., aiming to establish sustainability in the built environment as non-regulatory field able to generate radical change and innovation)[30]. To provide reasoning for adopting sustainability in buildings, many sources cite the economic benefits as the key motivators; which include energy savings, environmental gains, health and productivity improvement, or return premiums [29,31-34]. While climate change mitigation, awareness, social cohesion, resilience, quality, beauty and environmental stewardship seem to be some of the motivators cited in the more humanist approaches to the topic, a large portion of the design 
literature still responds to the market need for quantifiable benefitswhether political, social, economic, or environmental-in order to appeal to investors, governments and end-users [18,35-40]. Today, the definition of sustainability in the built environment has been primarily shaped by the available environmental assessment tools and standards [28,41]. Furthermore, the debates surrounding the definition of sustainability are inherently linked to and reinforced by the methods available for achieving it in building projects $[27,30,42,43]$. On the one hand, scholars suggest that sustainability in buildings can be achieved by satisfying sets of quantifiable criteria [1,2,7,44-46], while others are proposing to move away from quantification towards the qualitative comparison of projects with the help of analytical frameworks and maps [47,48].

It is certain that green building rating tools have gained popularity on an international scale [49]. Numerous sources which compare green building rating methods are available (they are also referred to as environmental assessment tools, building sustainability assessment tools, green building rating systems, sustainability assessment systems, or sustainable building assessment methods) [1-4,50-53]. Depending on the geographic origin of the research, different tools have been named as the "most famous", "most used" or "most widespread": in research originating from North America, LEED was identified as the most common (such as [50]), while in Europe BREEAM was identified as the prevailing system (such as [2,54]). Though LEED has the most citations in academic literature, BREEAM (originating from the UK) and HQE (originating from France) each have significantly larger numbers of building certified in their portfolio [2]. Thus, for researchers to focus on one or a few of the available methods, they directly limit the scope and implication of their work to regions where these methods are readily used. While the academic literature remains focused on rating and assessment, market reports (such as $[33,49,54,55])$ are highlighting, based on the surveys of practitioners and global market leaders in construction, key problems related to those systems: (1) $80 \%$ were in favour of a unified (single) green certification body rather than numerous options, (2) 53\% relate the benefit of using a green building rating system to marketing and competitive advantages, also from those who don't use the current systems (3) 79\% identified the cost related to rating as the main hurdle for not using the systems (a 20\% increase from 2015), and (4) $17 \%$ indicated that they find those ratings not ambitious enough. In light of this data, the validity of these tools to support global sustainable development could be questioned and it could be argued that the cost related to rating/certifying buildings could present real hurdles in underdeveloped and developing regions.

Some researchers have also proposed that the available tools distort the definition of sustainable development and overlook the synergies possible between the economic, social and environmental pillars [44,53,56]. Comparative studies revealed that almost all the most used tools (namely LEED, BREEAM, Green Star, CASBEE, SBTool, and ITACA) have energy as 
the main credit criterion [2,4,50,53]. While different references highlighted the benefits and gaps in each of those systems, another common finding across the studies is that the economic, institutional and social features of buildings are rarely considered in the tools [4,50,53]. Over the years many developments have been made to these systems, which have significantly expanded their scope and scale. However, considering this significant gap, the coherence of these tools with the UN 2030 agenda has to be studied in further depth. Additionally, and due to criticism of the unsuitability of analyzing the sustainability of a building in separation from its surrounding, a number of systems have introduced neighbourhood or regional level assessment methods-including LEED, CASBEE, BREEAM, DGNB [53,57]. While each of these systems provides specific benefits (in terms of focus categories or minimum requirements), the regional limitations which were mentioned for green building rating methods are still applicable to these tools (i.e., research using one or a few of these tools is limited geographically to regions where tools are readily used).

Díaz-López, Carpio, Martín-Morales and Zamorano in their critical analysis of sustainable building assessment methods published in 2019 [3] move beyond simple comparisons by assigning existing methods (specifically 36 of 101 identified methods) to 1 of 3 categories: (1) systems, where the level of sustainability of a building (and its sub-systems) is assessed, (2) standards, where minimum performance requirements are used to determine the compliance of a building and its systems with a set of pre-defined criteria, which are usually voluntary, and (3) tools, which are not geared towards compliance or certification but provide design teams with support tools for sustainable design. The methodology proposed in this research falls within the 3rd category-providing tools that can be used by building design teams to support sustainable design decisions.

Scholars have attempted to explore the decision making and design processes in architecture and planning projects but have identified a significant gap in the body of knowledge relating to sustainability decisions [58]. Scholars have also pointed to the fact that sustainabilityrelated decisions in the architecture, engineering and construction industry are still made without enough rigorous analysis [59]. In the design of commercial buildings, the sustainability decision-making process is solely focused on cost reduction (i.e., upfront or operational cost savings) or on achieving credits for green rating systems (such as LEED or others)[43]. These narrow-focused approaches reflect the concerns voiced in the literature on the use of assessment systems as design tools-such as those presented in [51,60,61]. While different theoretical models for planning and design present unique approaches to the topic of sustainability (e.g., as suggested in [58,62] these include transactive, scientific, advocatory, incremental or synoptic models), none has sustainable development explicitly as a core goal [58]. Additionally, and 
due to the large number of stakeholders involved in the decision-making process of commercial building design, there are often conflicting interests and a multitude of perspectives being presented during the IDP [43,63]. Moreover, scholars have highlighted many of the sustainability-related decisions, even in the context of the IDP [25,26], usually come late in the design process-resulting in loss of time and resources and also generating conflicts and tensions in the design team $[43,64]$. Today, with the multitude of adjectives describing projects and even cities (such as eco, resilient, low carbon, sustainable and many others), there is a need for unified definitions and frameworks regarding the urban future [29,43,64-67]. As highlighted in the recent literature, the 17 SDGs offer an opportunity to bridge the gap between the functionalist and human approaches to sustainability and to provide a unifying framework to guide the development of cities and building projects [11,13,15].

\section{The 2030 Agenda and Buildings}

The United Nations Conference on Sustainable Development held in 2012, known as Rio+20, concluded with the official text known as the Future We Want: Our Common Vision [14]. This document set out the key guidelines for global collaboration towards a comprehensive approach to sustainability and, in turn, led to the development of the 2030 Agenda and its SDGs (including its 169 targets and 230 indicators)[22,39]. The SDGs, which came as a successor to the Millennium Development Goals (MDGs), are structured around what are commonly known as the five Ps (Planet, Prosperity, Peace, People and Partnership) and are considered to be comprehensive to both human and natural needs [17,39,68-70]. Since the 2030 agenda came into effect at the beginning of 2016, there has been an increasing number of publications, by both academics and practitioners, which aim at analyzing its goals and targets; exploring its implementation means, processes and progress; studying its connection with existing policies and practices; or criticizing its economic growth focus or the contradictions within its targets $[16,18,69,71-74]$. Some of the available work also explores the consequences and links between the targets of the SDGs and specific economic sectors [75-77].

Allen, Metternicht and Wiedmann [18] intersected the national progress reports of 26 countries (i.e., reports submitted for review to the UN regarding the implementation progress for the SDGs) with the approaches and methodologies found in the academic literatureincluding implementation steps (such as action plans, mapping, consultation and others) and evidence-based approaches (such as benchmarking, multi-criteria analysis and others). They were able to find a number gaps in the reports (i.e., gaps between the reports content and the strategies and methods proposed in the academic literature); the most significant of these gaps are prioritization, quantitative modelling, policy evaluation, and need assessment related. They concluded that the current and most common approaches to the implementation of the SDGs are 
based on fitting and linking the goals with existing policies and programs and that there is a limited number of programs and policies specifically developed based on the agenda [22,70]. Gusmão Caiado, Leal Filho, Quelhas, Luiz de Mattos Nascimento and Ávila [22] found that some of the operational hurdles in the implementation of the 2030 Agenda require new strategic frameworks to be developed. They proposed a framework which is rooted in innovation, education, implementation and monitoring [22]. Their findings are critical in moving forward with the implementation of the SDGs since it indicates the inadequacy of the existing methods and processes to tackle the large scope of the agenda. Moyer and Bohl analyzed the possibility of achieving a number of human development targets under 5 different future scenarios that they built (namely: status quo, consumption pattern change, decentralized solutions, technology-led, or a combined approach)[68]. While they found limitations in the successful implementation of human development targets in all the scenarios explored, their most significant conclusion is that the goals and targets required to be completely reorganized under each of the scenarios (i.e., each scenario dictated its own priorities and presented different needs)[68]. Their findings are supported by the multi-criteria analysis conducted by Allen, Metternicht and Wiedmann [73], the assessment of the experts' SDG priorities conducted by Salvia, Leal Filho, Walter, Brandli and Griebeler [70], and the mapping and network analysis completed by Le Blanc [69]. By combining these academic findings, it can be concluded that, not only that existing programs and policies present gaps and limitations to the agenda's implementation, but that the priorities and focus of programs need to be adapted dynamically based on local factors (i.e., political, social, economic and environmental factors) and programspecific factors (i.e., its scope, nature, stakeholders and goals). This is significant in the context of sustainability in buildings since existing standards, programs and codes could present similar gaps and limitations. Additionally, the literature highlights the need for new, and more expansive, frameworks in order to achieve considerable progress in the implementation of the agenda.

In their 2018 paper, Alawneh et al. attempted to explore the nominal contribution of a number of LEED water and energy credits to SDGs 6, 7, $8,9,12,13$ and 15 with a specific geographic focus on Jordon (middle east) [24]. The authors used a questionnaire, completed by 55 local experts in green building, to propose a contribution index. They followed up this publication by an article [23] which explores more broadly the contribution of the assessment categories in 6 rating systems available (namely LEED, BREEAM, CASBEE, Green Star, Green Mark and GBI) to SDGs 3, 6, 7, 8, 9, 11,12, 13 and 15 (with a nominal reference to all SDGs). In this 2019 article, the authors use the Delphi method (with 45 local experts) to further validate the contribution index they calculate for each credit category and then propose a framework to integrate assessment indicators into non-residential building projects in Jordan. While these 
studies highlight some of the synergies that could be available between rating tools and some of the SDGs, the results presented are limited to the geographic area of focus (namely Jordan). Additionally, the paper did not explore how such contributions can be achieved (i.e., they do not present practical examples) and do not provide a concrete methodology for localizing (scaling down) the goals to the project level. Instead, their methodology presupposes that achieving a specific requirement or indicator in the rating system automatically generates a contribution to the SDG. Finally, and in contrast to the findings of researchers focused on the 2030 Agenda, the findings propose positive contributions to the SDGs for all indicators investigated and do not explore some of the trade-offs which might be present as proposed by $[22,68,73]$. Furthermore, and although this approach is a positive first step, it reinforces the current building practices and does not aid in the development of new, more sustainable, approaches for building design [53]. To the best of the authors' knowledge, there are no academic or industry references which investigate the critical design integration of the SDGs in building projects, and no references which propose practical tools to help designers in such integration. Additionally, no global-scale studies have been found which investigate the synergies and trade-offs between the SDGs and their targets with various available green building tools (such as LEED, CASBEE, BREEAM and SBTool), their sub-systems (i.e., for new buildings, communities, or neighbourhoods).

Other researchers have proposed expansive and universal methods to assess the integration of SDGs in projects and strategies [12]. However, the complexity of the assessment process and the lack of customization present hurdles to their use in building projects. As Brandon and Lombardi suggest, the global focus of the agenda makes its implementation complex and requires new collaborations between a bigger number of actors [7]. Thus, to fully utilize the transformative potential of the 2030 agenda there is a need to explore innovative and collaborative tactics. This would require the SDGs to be introduced in the early design phases of projects [78]. The IDP, which has become common practice for high-performance and green buildings, offers the opportunity for such early integration while fostering constructive collaboration between the different stakeholders of building projects [26,79,80]. Although some of the SDGs are linked to quantifiable indicators, mapping tools, which enable a pluralistic understanding of the topics and content of the agenda, are seen to be more adapted for the integration of the SDGs in early phases of building projects [30,81-83].

\section{The Integration of Sustainability in Design}

Although the IDP's main goal is to harmonize the design intents of different stakeholders and to streamline the design decision-making process [26], it does not intend to blur the line between the duties of the different experts: each expert on the team is expected to positively share 
their knowledge in their respective fields in order to solve the often complex problems connected to the design and operation of sustainable buildings [84]. The IDP literature usually distinguishes between the architectural and engineering concerns in buildings design-the first dealing with volumetric, aesthetic, material, visual, and functional qualities, while the latter addressing issues related to energy solutions and targets, indoor environment, technology, building systems and controls [26,80,84]. Additionally, current practices of IDP are increasingly considering the complete life cycle of buildings-including the building operation and post-occupancy phases [26,80]. To meaningfully consider these late phases requires including the building operators (i.e., building owners and the operation \& maintenance staff) within the IDP [25]. The operational dimension of the building often addresses issues related to management, maintenance, operation and usage, and programming. Recently, in state-of-the-art sustainable buildings, building operators and owners are also frequently expected to implement awareness and educational programs-these usually entail tours and presentations that describe the sustainability features of their building to the public $[85,86]$. It is important to note that the specific dynamics of each IDP team depends on the planning and design model followed and on the decision-making process adopted. In some projects, simpler, more flexible and more inclusive processes are used which could provide stronger connections with the objectives of sustainable development [48,58,62]. Thus, even in an IDP context, the main pillars of building design can still be considered architectural, engineering, or operational in nature.

Various theoretical models and approaches are available to measure or assess the level of sustainability or its integration in products, services or designs [87-91]. In his seminal publications, Brezet [92,93] proposed one of the most used theoretical models for categorizing the levels of sustainable design, (what at that time was commonly known as eco-design). He proposed 4 distinct levels: (1) product improvements, (2) product redesign, (3) functional innovation, and (4) system innovation. In their article published in 2001, Fletcher and Goggin [94] divide eco-design approaches into 3 distinct categories: (1) product-focused: an approach which focuses on improving the efficiency of existing product and services; (2) results-focused: an approach focused on producing the same outcome or result in different, more sustainable manner; and (3) needs-focused: an approach which questions the need to be fulfilled and its mode of fulfilment. Cucuzzella, by using the work of Dewberry [89-91], Brezet [93] and Fletcher and Goggin [94], proposes to combine Brezet's first 2 levels into what can be considered a product optimization stages, and the last two levels into innovation-based stages [95]. Thus, it can be understood that by increasing the integration of sustainability in a design requires an increased level of innovation. Bhamra [87] further defines this by distinguishing the two basic levels of sustainable design: (1) incremental, where environmental and sustainability issues are 
considered as technical problems that should be solved using technology, efficiency, optimization; and (2) innovative, where sustainability issues are used as the driver for new and more radical concept development that can be approached by marrying culture, technology, nature and creativity. In the field of building design, the incremental approaches have been usually linked to the use of sustainability assessment tools-which are rooted in an optimization and eco-efficiency mode of reasoning $[6,8,48,53,63,96]$. By combining the theoretical models presented, 4 levels of sustainability integration in buildings can be proposed: (1) not considered, (2) following available standard practice (i.e., where a specific issue is considered based on current standard practice), (3) incremental improvement rooted in optimization and efficiency (i.e., rooted in current modes of design and assessment), (4) innovative (i.e., where the design shows signs of functional or system innovations by moving beyond optimization strategies).

\section{Sustainable Design Approaches}

Instead of an incontestable approach to sustainability, which ignores local knowledge along with social, economic and ecologic realities, scholars suggest to understand approaches to sustainability as design logics [97,98]—where logic can be defined as a group of ideas or concepts, which give meaning to social and physical reality, that can be produced and reproduced, and that can develop through practice [99,100]. As such, and based on Schön's ideas, sustainability could be perceived as an emergent property of design thinking through reflection-in-action [44,101-103]. Nelson and Stolterman highlight that design enables the creation of objects which reflect the conditions the world "ought to be" by enabling human intentions to reshape the world [104]. For the authors, designers create the "real" world through their endeavours by materializing the sought-after state of the world that the involved parties desire. Jean-Pierre Boutinet places projects in the "partially determined" mode of anticipation [105]; for him, the project is an anticipation of the desired future [105]. In the context of IDP in building design, this sought after state should encompass the collective desires of the stakeholders and design team $[26,80]$. The 2030 Agenda, although not often considered as a design project, shares a number of commonalities with projects and design: it presents an outlook for the desired future (i.e., what the world ought to be) which was imagined through an inclusive participatory process [22]. In fact, the agenda reflects the four characteristics of projects proposed by Boutinet: (1) a global approach that is beyond the sum of its objectives, (2) a singular approach that seeks original responses to specific situations, (3) a tool for dealing with complexity and uncertainty, and (4) an open system (System in this context is used to refer to system thinking approaches [106-108]) that allows for modifications [105].

Boutinet proposes to analyze projects based on their motivational (technic vs existential) and anthropological (collective vs. individualistic) 
nature $[105,109,110]$. The motivational axis of Boutinet's map reflects a common tension in building project between social consideration and technological integration-one that has been also explored by Guy and Farmer [97]. Fry proposes the notion of "futuring" for rethinking sustainability in building projects [111]. For Fry, futuring is a re-directive practice that is tuned towards helping sustain humanity, the planet and other species-an approach that is future driven [111]. On the other hand, Fisher calls for rethinking our efficient connected mode of living and to replace them by a more vernacular model that is inherently more resilient-an approach that is history driven [112]. He sees a need for using indigenous talent and practices, local materials, along with traditional and cultural principles in order to succeed in building cohesive communities and to re-connect with nature [112]. Table 1 summarizes the key models presented in the literature review and their relevance to the methodology of this paper.

Table 1. Summary of theoretical models and literature reviewed and their relevance to the methodology of the article.

\begin{tabular}{llll}
\hline Subject & Relevant Literature & Specific References \\
\hline Fields of sustainable building design & Integrated design theory and practice & {$[25,26,48,58,62,80,84-86]$} \\
\hline \multirow{2}{*}{ Integration of sustainability in design } & $\begin{array}{l}\text { Theoretical models of eco-design } \\
\text { (sustainable product design theory) }\end{array}$ & {$[6,8,92-96,48,53,63,87-91]$} \\
\hline \multirow{3}{*}{$\begin{array}{l}\text { Sustainable design } \\
\text { approaches }\end{array}$} & $\begin{array}{l}\text { The motivation and character of } \\
\text { the approach }\end{array}$ & $\begin{array}{l}\text { The theory of projects and their } \\
\text { trajectories }\end{array}$ & {$[44,97,109,110,98-105]$} \\
\cline { 2 - 5 } & The inspiration and influence & $\begin{array}{l}\text { Theory and practice of sustainable design } \\
\text { (ethics of sustainable design) }\end{array}$ & {$[44,101-103,111,112]$} \\
\hline
\end{tabular}

\section{Concluding Remarks of Literature Review}

The review of the literature pertaining to sustainability in buildings revealed an ongoing tension between functionalist approaches which aim to establish sustainability in the built environment as a pragmatic field guided by quantitative standards and humanist approaches which aim to establish sustainability in the built environment as a non-regulatory field able to generate radical change and innovation. Sustainability and green rating and certification methods constitute a substantial portion of the available research. Comparative studies of the most prominent certification and rating tools revealed a focus on the environmental dimension and general inattention to the social and economic dimensions of sustainability. Based on the findings reported in the literature, assessment and certification tools were also found to be regionally dependent and presenting some limitations due to the costs needed for certification. Stemming from these limitations, a humanist approach, focused on change and innovation, was found to be the most appropriate for developing a broad approach for integrating the SDGs in building design. To the best of the author's knowledge, there were no references 
which aimed at utilizing 2030 Agenda itself as the basis of a framework for understanding and approaching sustainability in buildings.

The literature pertaining to the SDGs was mainly distributed between studies that analyze the agenda itself (i.e., focusing on links, synergies and trade-offs between the goals and targets) or its means of implementation (through prioritization and scenario building). The findings of the literature highlight the strong interlinkages between the SDGs and their targets and the tendency to fitting and linking the goals with existing policies and programs. Additionally, the findings of sources in the first category point to the fact that the priorities and focus of programs and projects need to be adapted dynamically based on local factors and program/project-specific factors. The research which aimed at intersecting sustainable building design with the SDGs followed the same strategies, where exiting credits and rating tools were fitted and linked to the goals with a regional and topic-specific focus. To the best of the authors' knowledge, there are no academic or industry references which investigate the critical design integration of the SDGs in building projects, and no references which propose practical analytical tools to help designers achieve such integration.

This research aims to address those two gaps by (1) utilizing the SDGs and the 2030 Agenda as a framework for approaching and analyzing sustainable building design, and (2) design and test practical analytical tools which could be used in the early design stages to meaningfully and critically integrate the topics of the 17 SDGs in the design of buildings.

The IDP literature was found to be the most appropriate when exploring the process of integrating sustainability in building design. The reviewed sources highlighted that the process aims at mediating between the architectural and design concerns, the engineering concerns, and operational concerns. The literature which aimed at assessing the level of integration of sustainability in design distinguished between incremental approaches (which frame sustainability issues as technical problems and are usually focused on harm reduction, optimization and product redesign) and innovative approaches (which frame sustainability issues as a driver for innovations). To understand the approaches to sustainable design, a number of important design and sustainable design theory references were reviewed (summarized in Table 1). The methodology section presents how the integration and design literature was used for constructing the analytical tools for this research.

\section{METHODOLOGY}

\section{Mapping the Integration of SDGs in Building Projects}

As reviewed in the previous section, the analytical map (Figure 1) proposed for assessing the integration of the SDGs in building projects is structured around the three fields (axes) which are usually considered in the IDP (namely, Architecture, Engineering and Operations)[26,80]. By 
using the levels of integration presented from the available literature [12], the map proposes 4 distinct levels of integration for each of the three axes:

- Level 3: Innovative integration: This highest-level of integration entails developing innovative approaches to tackle the specific SDG topic in the design and planning for the project;

- Level 2: Beyond precedents: This level entails augmenting the available approaches and standards to the SDG topic-i.e., using the criteria of existing approaches or tools while refining them or surpassing their performance requirements;

- Level 1: Standard or precedent driven: This level of integration entails using and depending on the criteria in available examples and standards for addressing a specific topic;

- Level 0: Not Integrated: Since each of the goals' integration will be analyzed for each of the 3 axes, some goals might only be integrated into one dimension of the project-making them not integrated on the other axes (i.e., integrated at level 1).

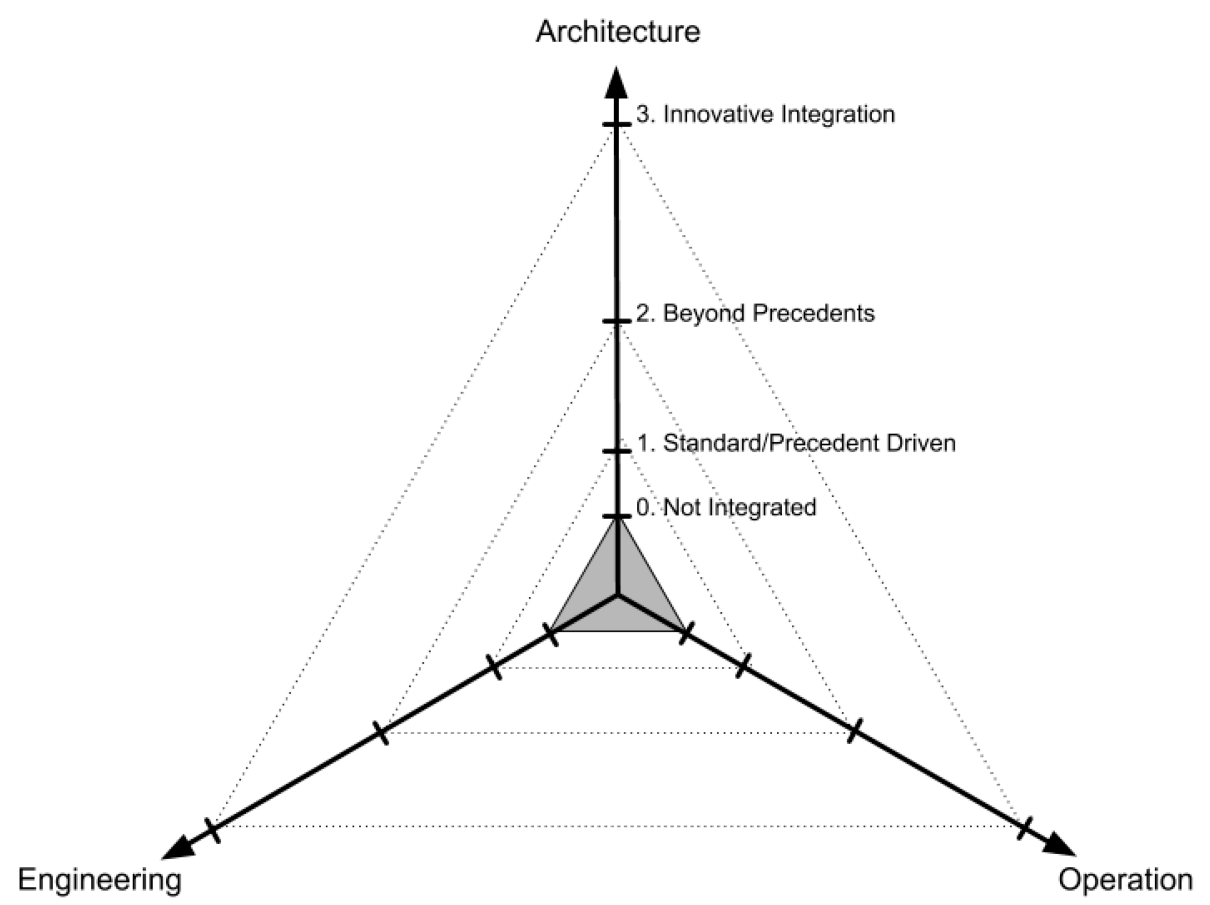

Figure 1. Proposed mapping tool for evaluating the SDG integration in building projects.

Since SDG 11 (make cities and human settlements inclusive, safe, resilient and sustainable) has been cited as one of the most relevant to the construction industry $[63,77,113]$, it can be used as an illustrative example for these different levels of integration across the 3 axes. Within SDG 11, the most relevant targets to building projects include: target 11.4 (protecting cultural and natural heritage), target 11.6 (reducing per capita impact of cities-specific attention to air quality and waste management), target 11.8 (access to green and public spaces), and target 11.B (local 
disaster risk management). Table 2 presents some of the possible building features which relate to SDG 11.

Table 2. Example of building features which relate to SDG 11 across the 3 axes and the 3 levels of integration (excluding level 1: not integrated).

\begin{tabular}{|c|c|c|c|}
\hline Axis & Level 2 & Level 3 & Level 4 \\
\hline $\begin{array}{l}\text { Architecture } \\
\text { (focus on target } \\
\text { 11.8: access to } \\
\text { green and } \\
\text { public spaces) }\end{array}$ & $\begin{array}{l}\text { Meeting requirements for } \\
\text { outdoor and green spaces: } \\
\text { such LEED’s } 30 \% \text { and } 25 \% \text { of } \\
\text { total site area for outdoor and } \\
\text { green spaces proposed for } \\
\text { new buildings [114] }\end{array}$ & $\begin{array}{l}\text { Providing more open and green } \\
\text { spaces than the current standard: } \\
\text { such as providing more than } 30 \% \\
\text { outdoor spaces and more than } 25 \% \\
\text { green spaces. }\end{array}$ & $\begin{array}{l}\text { Providing more outdoor and green } \\
\text { spaces than required by available } \\
\text { standards while presenting new } \\
\text { approaches for integrating green and } \\
\text { outdoor spaces within the building } \\
\text { (such as semi-enclosed spaces or } \\
\text { seasonal based outdoor-indoor } \\
\text { spaces) and maximizing the access to } \\
\text { the outdoor spaces and ensuring the } \\
\text { high quality of their design. }\end{array}$ \\
\hline $\begin{array}{l}\text { Engineering } \\
\text { (focus on target } \\
11.6 \text { (reducing } \\
\text { per capita } \\
\text { impact of } \\
\text { cities-specific } \\
\text { attention to air } \\
\text { quality and } \\
\text { waste } \\
\text { management) }\end{array}$ & $\begin{array}{l}\text { Complying with for pollutants } \\
\text { control and air quality } \\
\text { standards and controlling } \\
\text { waste. This could be based on } \\
\text { meeting the criteria proposed } \\
\text { by LEED for new buildings on } \\
\text { indoor air quality and control } \\
\text { of pollutants, as well as } \\
\text { collection and storage of } \\
\text { recyclables or controlling } \\
\text { construction waste [114] }\end{array}$ & $\begin{array}{l}\text { Aim at achieving better control on } \\
\text { pollutants which affect air quality } \\
\text { both indoor and outdoor (such as } \\
\text { carbon emissions and chemicals) } \\
\text { through the use of advanced filters } \\
\text { and avoidance of use. Additionally, } \\
\text { focusing on creating a } \\
\text { comprehensive waste management } \\
\text { strategies and technologies that } \\
\text { move beyond than recycling to } \\
\text { consider reduction and reuse. }\end{array}$ & $\begin{array}{l}\text { Along with the strategies from level 3, } \\
\text { the building could integrate } \\
\text { engineered waste management } \\
\text { solutions on-site (such as small-scale } \\
\text { composting facilities, or a compactor } \\
\text { to reduce the emissions related to } \\
\text { waste transport). The building could } \\
\text { also set zero air pollution targets-by } \\
\text { ensuring the use of clean energy } \\
\text { technologies. }\end{array}$ \\
\hline $\begin{array}{l}\text { Operation } \\
\text { (focus on target } \\
11.4 \text { protecting } \\
\text { cultural and } \\
\text { natural } \\
\text { heritage) }\end{array}$ & $\begin{array}{l}\text { Implement a comprehensive } \\
\text { site management policy to } \\
\text { reduce harmful chemical use, } \\
\text { energy waste, water waste, } \\
\text { air pollution, solid waste, } \\
\text { and/or chemical runoff: such } \\
\text { as meeting the criteria } \\
\text { proposed by LEED for } \\
\text { operation and maintenance } \\
\text { of sites [114]. }\end{array}$ & $\begin{array}{l}\text { Introducing policies that are centred } \\
\text { around protecting, promoting and } \\
\text { restoring biodiversity on the site-- } \\
\text { moving beyond harm reduction. This } \\
\text { would entail reintroducing native } \\
\text { vegetation to the site beyond the } \\
\text { current LEED requirements of } 20 \% \\
\text { from the site area [114]. The } \\
\text { operation could also aim at } \\
\text { minimizing disturbances to existing } \\
\text { ecosystems on the site. }\end{array}$ & $\begin{array}{l}\text { Developing a non-anthropocentric } \\
\text { management and operation plan for } \\
\text { the building by considering the well- } \\
\text { being of different creatures occupying } \\
\text { the site. This could include } \\
\text { maintaining and supporting the } \\
\text { habitats for animals, insects, and } \\
\text { plants as part of the operation plan. }\end{array}$ \\
\hline
\end{tabular}

\section{Analyzing the Design Approaches to the SDG Topics}

To develop an analytical map for design approaches to the SDGs in building projects, its axes have to be constructed to fit the theoretical underpinnings of design presented by Nelson and Stolterman [104], the anthropology of projects presented by Boutinet as well as the transformative vision of the 2030 Agenda $[15,105]$. Boutinet's motivational 
axis can be understood in the context of buildings as the design character moving from human to product-focused [105,110]. Human-focused approaches place the users, society and communities at their core (i.e., focusing their attention on providing people with opportunities through design), while product-focused approaches are concerned with technologies, products and the materiality of the project (i.e., focusing on integrating and improving on the material products). Additionally, the two concepts that Fry and Fisher [112,115] present could be used to as the second axis of the analytical map: what could be understood as the design inspiration moving from history to future driven approaches [111,112,116]. History driven approaches are inspired by the traditional and historical ways of doing things and the intent to return to an earlier and more sustainable state (i.e., inspired by how people traditionally used to live, interact together and with nature, build, or use spaces) while future driven approaches aim at innovating new ways by using contemporary tools and systems and to create new states which could be more sustainable (i.e., inspired by the possibility of creating new ways for people to live, interact together and with nature, built or use spaces). Figure 2 presents the resulting map.

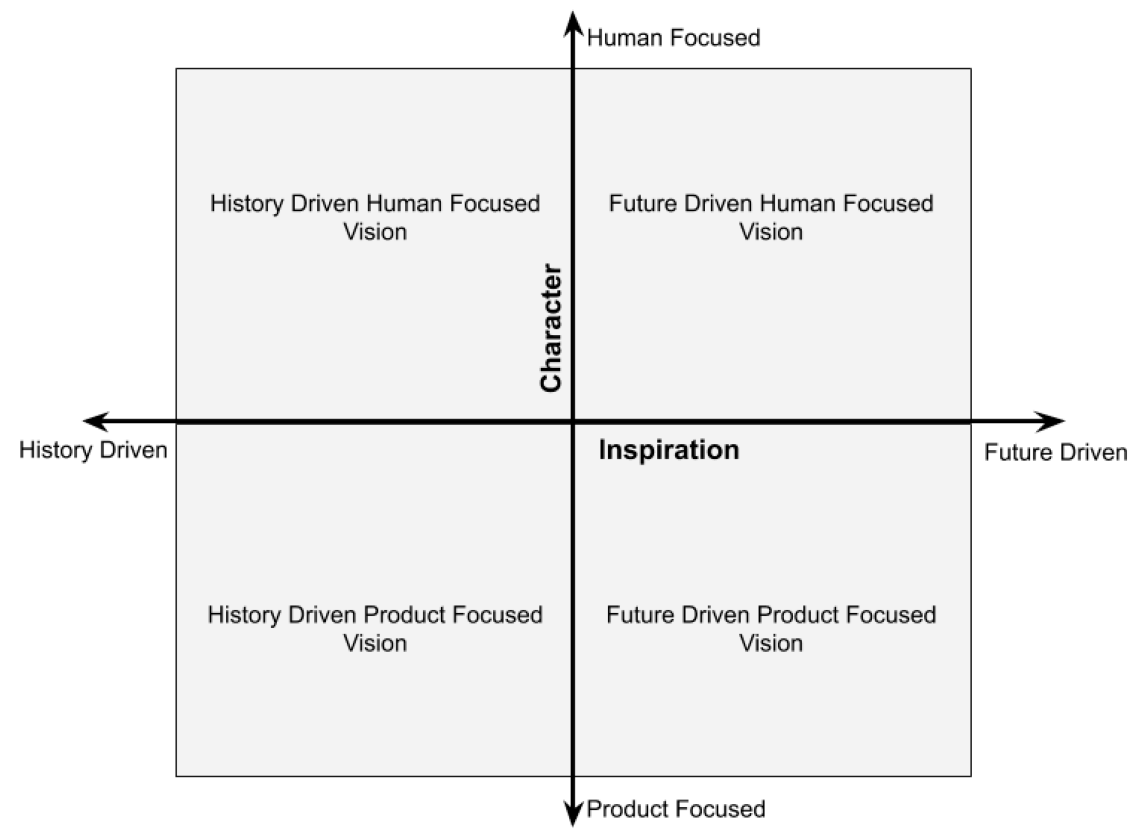

Figure 2. Proposed mapping tool for analyzing the sustainable design visions (SDVs) around the SDG topics.

Mapping the approaches to the SDGs topics on the two proposed axes provide a mean to analyze the visions manifested in the design-the sought-after state regarding the specific SDG topics. Since the 2030 Agenda presents key goals to be achieved, the different quadrants could be understood as sustainable design visions (SDVs) which embody the design team's proposed mean for attaining the SDGs. The map offers 4 distinct quadrants: (1) history driven human-focused visions; where traditional modes of human interactions are seen as the mean for addressing a 
specific SDG; (2) Future driven human-focused visions; where new modes of human interaction-such as those depending on information and communication technologies-are seen as the mean for addressing a specific SDG; (3) History driven product-focused visions; where vernacular modes of construction and design are seen as the mean for addressing a specific SDG, and (4) Future driven product-focused visions; where new technologies and products are seen as the mean for addressing a specific SDG.

\section{Adapting the SDGs and their Targets for Building Projects}

Although the 2030 Agenda offers a comprehensive and internationally applicable set of goals and targets, they must be reinterpreted to facilitate their application in building projects. The Oslo Manifesto [117] offers an example of such interpretation; where the goals are reiterated as broad design questions for creative professionals. Additionally, the recently published architecture guide to the UN 17 SDGs by the Institute of Architecture and Technology (KADK), The Danish Association of Architects and The UIA Commission on the UN Sustainable Development Goals offer another important reference for design teams [118]. However, to cater further to the needs of building design teams, a reinterpretation of the goals was required. Appendix 1 provides a list of the 17 goals, their respective building design question accompanied by a list of buildingrelated elements. The building-related elements were extracted from the list of targets for each goal based on their relevance to building projects.

\section{METHOD}

\section{The Application of the Proposed Methodology}

To apply the proposed mapping tools in the early design phase of building projects, a 4-stage implementation process is proposed. Since not all the 17 goals apply to all projects, the first step aims at identifying and selecting the most relevant SDGs for a given project. This exercise could be completed within the IDP—specifically in early design charettes [26,119]and requires intersecting the goals and mission of the project with the 2030 Agenda. Additionally, the design team should also strategize and discuss the means for attaining the selected goals and the synergies between them. The second step aims to assess the integration level of the selected goals. This step could be completed when approaching the end of the schematic phase of the project [23]. The level of integration could be assessed by the design team members and project stakeholders with the help of surveys. The results of this survey should also be discussed collectively in the design charettes. In very large integrated design teams and depending on the team members' expertise (i.e., the coherence of their expertise and roles in the project), the Delphi method could be used to arrive at a consensual assessment of the integration [120]. However, if the Delphi method is used, the research team will have to ensure the 
continued anonymity of the responders-which could limit the ability of the researchers to divide the responses based on the team members' roles on the team. The third step of the process entails identifying the specific design features that support the integration of the selected goals in the project. This step can be completed using collective discussions within the IDP or the design charettes [119,121]. The identified design features could be linked to specific targets within each goal. Depending on the integrated design team's dynamics and coherence, the Delphi method could be used in place of the collective discussion. Finally, the SDVs can be mapped in order to present the design approaches specific to each of the SDG selected as well as the project's overall vision. The application process is summarized in Figure 3. As a final note, if the research is being carried out for multiple projects simultaneously, involves multiple design teams or involves a large number of stakeholders, the Delphi method is recommended in order to further harmonize and validate the results across the cases.

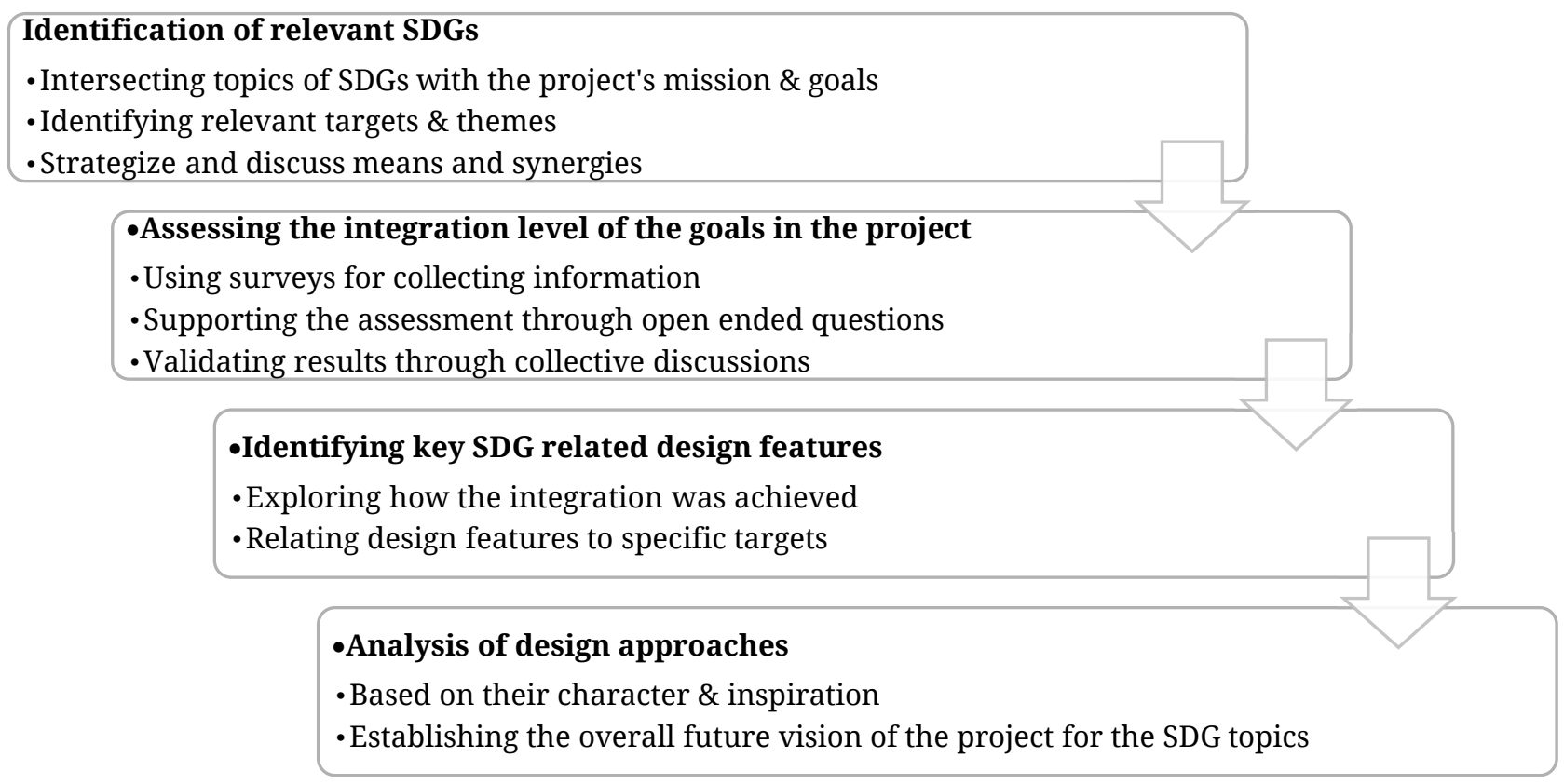

Figure 3. The implementation process for proposed tools.

For this research, and in order to illustrate the applicability of the analytical maps and methodology proposed, a case study for the design of an energy positive and low-carbon building in Quebec (Canada) is used. A real-life case study was selected, as opposed to hypothetical examples, in order to better help practitioners and researchers apply and adopt the tools presented. Since the researchers were integrated within the design team of the case study, the paper presents specific insights regarding the project which were gained through the participation in the design charettes and the access to the meeting minutes and presentations. The case study is presented in full detail in the next subsection. Due to the harmony of the design team (i.e., well-integrated design process with no 
internal conflicts or tensions) as well as the team's specific composition (i.e., small, made of researchers, practitioners and students), the researchers used a simple survey and collective group discussions as methods for collecting the data. Collective discussions are considered an appropriate method for decision making within the IDP since, as a dialectic method, it is able to reveal and resolve dissensus within the team [84,121]. Table 3 details the specific methods used for each of the steps proposed in the methodology.

Table 3. Methods used in this research to apply the methodology steps proposed.

\begin{tabular}{ll}
\hline Methodology Step & Method \\
\hline Selection of relevant SDGs & Collective group discussion moderated by researchers [26,80,121] \\
\hline $\begin{array}{l}\text { Assessment of the level of SDGs } \\
\text { integration }\end{array}$ & $\begin{array}{l}\text { Survey-quantitative assessment supported with open-ended comments } \\
{[122,123]}\end{array}$ \\
\hline Validating assessment results & Collective group discussion moderated by researchers [26,80,121] \\
\hline Identifying design features & $\begin{array}{l}\text { Collective group discussion moderated by researchers [26,80,121] and } \\
\text { knowledge gained through the design charettes (as available in the meeting } \\
\text { minutes and charette presentations) }\end{array}$ \\
\hline Identifying design approaches & $\begin{array}{l}\text { Knowledge gained through the design charettes (as available in the meeting } \\
\text { minutes and charette presentations) - analysis conducted similar to [83] }\end{array}$ \\
\hline
\end{tabular}

\section{Case Study Description: The UQROP Interpretation Center in Saint-Jude, Quebec}

In order to illustrate, test and validate the proposed method, this paper uses a case study for a high-performance bird interpretation center for Union Québécoise de Réhabilitation des Oiseaux de Proie (UQROP, The Quebec Union for the Rehabilitation of Birds of Prey, https://www.uqrop.qc.ca/en/) in Quebec, Canada. The main mission of the UQROP is to protect the birds of prey and their natural habitats. For their new interpretation center at Saint-Jude (Quebec, Canada), the UQROP decided to augment their commitments to environmental protection by setting ambitious targets: they intend to build a state-of-the-art facility that integrates technologies, systems and design to achieve a well-designed, highly resource-efficient, energy positive, and low-carbon building. The new building will be located on a 22 hectares land in the heart of one of the largest protected forests in the region. The land, currently used by the UQROP for their seasonal activates, encompasses 4 different natural habitats, and features more than $2.5 \mathrm{KM}$ of pedestrian trails. The new interpretation centre is designed to welcome approximately 40,000 visitors per year. This project constitutes an important milestone in the expansion of the UQROP since it will enable them to welcome visitors on the site throughout the year, to expand their educational program through permanent and temporary exhibitions, and to diversify their activities using flexibly programmed spaces. The building will also house a 
veterinary facility and a winter shelter for birds. Figure 4 presents a preliminary design illustration for the building.

The UQROP building aims to be one of the most energy-efficient institutional buildings in Quebec and Canada-with a target energy use intensity of $60 \mathrm{kWh} / \mathrm{m}^{2} \cdot \mathrm{yr}$. The building integrates several key technologies such as predictive controls, a building-integrated photovoltaic and thermal system (BIPVT) and a direct expansion $\mathrm{CO}_{2}$ geothermal system. The integrated design team for the project is composed of more than 20 researchers, practitioners, and artists from the fields of design, architecture, building engineering, controls, animation and museology: including more than 8 students, representatives from the UQROP staff and board, as well as facilitators. The integrated team is a result of a collaboration between the UQROP (a non-governmental, not for profit organization and network), with Concordia University (a publicly owned university - with a number of research centers and programs involved, including the Center for Zero Energy Building Studies (CZEBS) https://www.concordia.ca/research/zero-energy-building.html and the Concordia University Chair for Concordia University Research Chair in Integrated Design, Ecology And Sustainability for the Built Environment (ideas-be)-http://www.ideas-be.ca/mission.html) and a number of practitioners from the building industry (including structural, and building systems engineering firms as well as the building's general contractor). Additionally, some of the team members are also affiliated with public research institutions (such as CanmetENERGY: The Natural Resource Canada (NRCan) clean energy research division).

Beyond the environmental targets, the building's exhibition spaces were also used as an opportunity for research-creation projects which combine different art and design practices to innovatively communicate information about Quebec's birds of prey, the history of the site and SaintJude, as well as the sustainability features of the project. Moreover, the engineering experts on the team are expected to suggest modifications and additions to buildings codes: in order to better adapt the codes to the future challenges and opportunities high-performance buildings offer and to streamline the integration of state-of-the-art technologies in buildings.

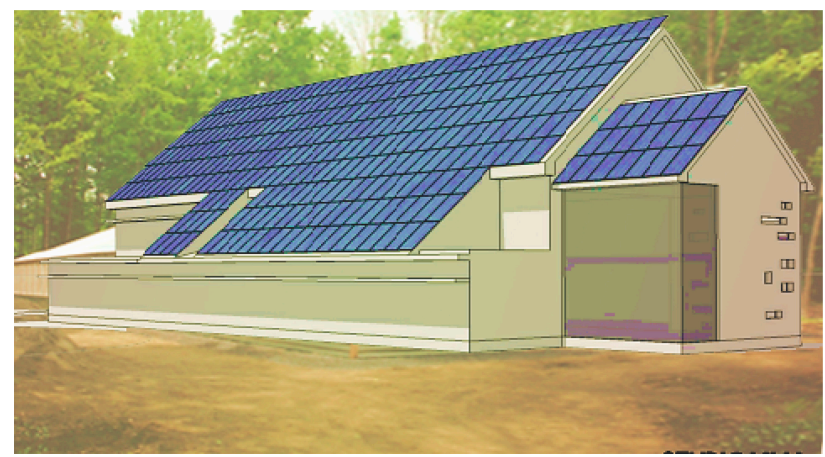

Figure 4. Preliminary design illustration of the UQROP interpretation center-image credit: Studio MMA. 
The UQROP project constitutes an important case study for this research since the union's mission is centred around biodiversity protection, education, skill-building, partnership, and sustainable tourism. Additionally, the new interpretation center will significantly expand UQROP's sustainability mission to consider challenges related to energy, water, innovation, and equitable growth. The project IDP was initiated in October 2018 and progressed until March 2019—concluding the schematic design phase of the project.

\section{RESULTS AND DISCUSSION}

During the early design charettes, 8 of the SDGs were identified as relevant focus points for the project: SDG 4 (education), SDG 6 (water), SDG 7 (energy), SDG 8 (sustainable growth), SDG 9 (sustainable infrastructure and innovation), SDG 11 (sustainable cities), SDG 15 (terrestrial ecosystems) and SDG 17 (partnership). By early November, and following several facilitated sessions around these 8 SDGs, a survey for assessing the integration of SDGs in the building was prepared and distributed to the team.

\section{Results}

Overall 18 members of the design team completed a surveygenerating more than 430 data points-to assess the integration of the 8 SDGs in the schematic design of the building. Each team member assessed the integration level (from 0 to 3 ) across each of the 3 axes for each of the 8 selected SDGs. Additionally, for each goal, an open-ended response section was provided for the team members to justify and explain their assessment. To ensure that the team was well informed, the building design question and the building-related elements for each goal were also provided within the survey. The results of the assessment were analyzed on two main levels: (1) compiled overall integration level assessment; where the average integration level across the 3 axes was calculated for each SDG; (2) The axis-based integration level assessment, where the integration level for each axis was calculated for each SDG. Additionally, the responders were divided into three groups: (1) Designers (researchers, students and practitioners in the field of design and architecture) which included 6 respondents; (2) engineers (researchers, students, and practitioners in the field of engineering) which included 8 respondents, and (3) non-designers (managers and facilitators) which included 4 respondents.

\section{Compiled overall integration level assessment (8 SDGs)}

The compiled overall level of integration assessment for each of the 8 goals is presented in Figure 5. The average assessed integration for all the 8 SDGs was assessed to be 1.9-suggesting that the design moves beyond the available standards and criteria. The average integration levels for 
SDG 6, SDG 7, SDG 9, and SDG 17 were assessed to be 2 or above-with SDG 7 (energy) assessed to be the most integrated in the project (these 4 highly integrated goals will be used for the detailed analysis in the next section of the paper). By comparing the overall assessment completed by each of the three groups, several observations can be made. (A) Designers were the most critical in their assessment: they constantly assessed the integration of each of the 8 SDGs the lowest with an overall average of 1.5. Designers only indicated an integration level of 2 for SDG 7. (B) nondesigners consistently assessed the integration to be the highest with an average of 2.4 across all the 8 SDGs. Non-designers also assessed SDG 11 (sustainable and resilient cities) at a significantly higher level than the 2 other groups. (C) The assessment of designer and engineers followed the same pattern where the 4 SDGs highlighted in Figure 5 were assessed to be the most integrated into the project.

3

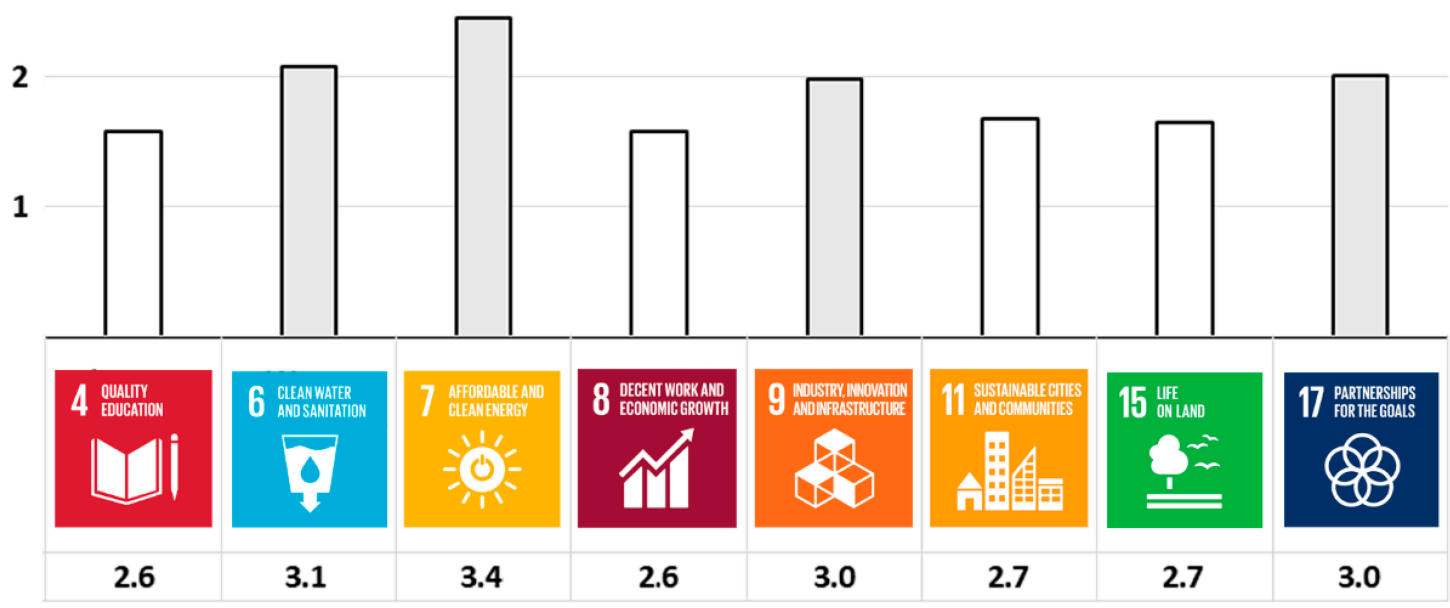

Figure 5. Compiled overall integration level assessment for the 8 selected SDGs-highlighted in grey are the goals which were assessed by the team to have an integration level of 2 or above.

The use of one survey revealed differences in the assessment of integration between the 3 groups of responders. Unlike in a Delphi method, where multiple rounds of surveys are used to arrive at a consensual assessment, the research team used a dialectic method through collective team discussion to investigate the reasons behind these differences. The main reasons, as identified during the discussions, included differences in expectations (i.e., designers expected the topics to be integrated more deeply in the design), differences in benchmarking (i.e., where managers, the client and non-designers were comparing the level of integration to conventional construction projects while the other 2 groups used more state-of-the-art references), and differences in the consideration of limitations (i.e., some of the groups assessment was made in reference to the specific limitations of the project-in budget, program and client needs-while others assessed the integration in broader sense). However, the integrated design team identified that these differences are 
useful within the IDP in order to further develop the project (in subsequent phases beyond the schematic design) and align the collective goals of the different stakeholders. While these variations might be seen as limiting the applicability of the results beyond the specific project, the goal of the assessment process proposed in this paper is to assist the project team in addressing the SDG topics and reflecting on the relevance of their design approaches to the 2030 Agenda. Figure 6 presents the compiled overall integration level assessment as rated by each group of responders.

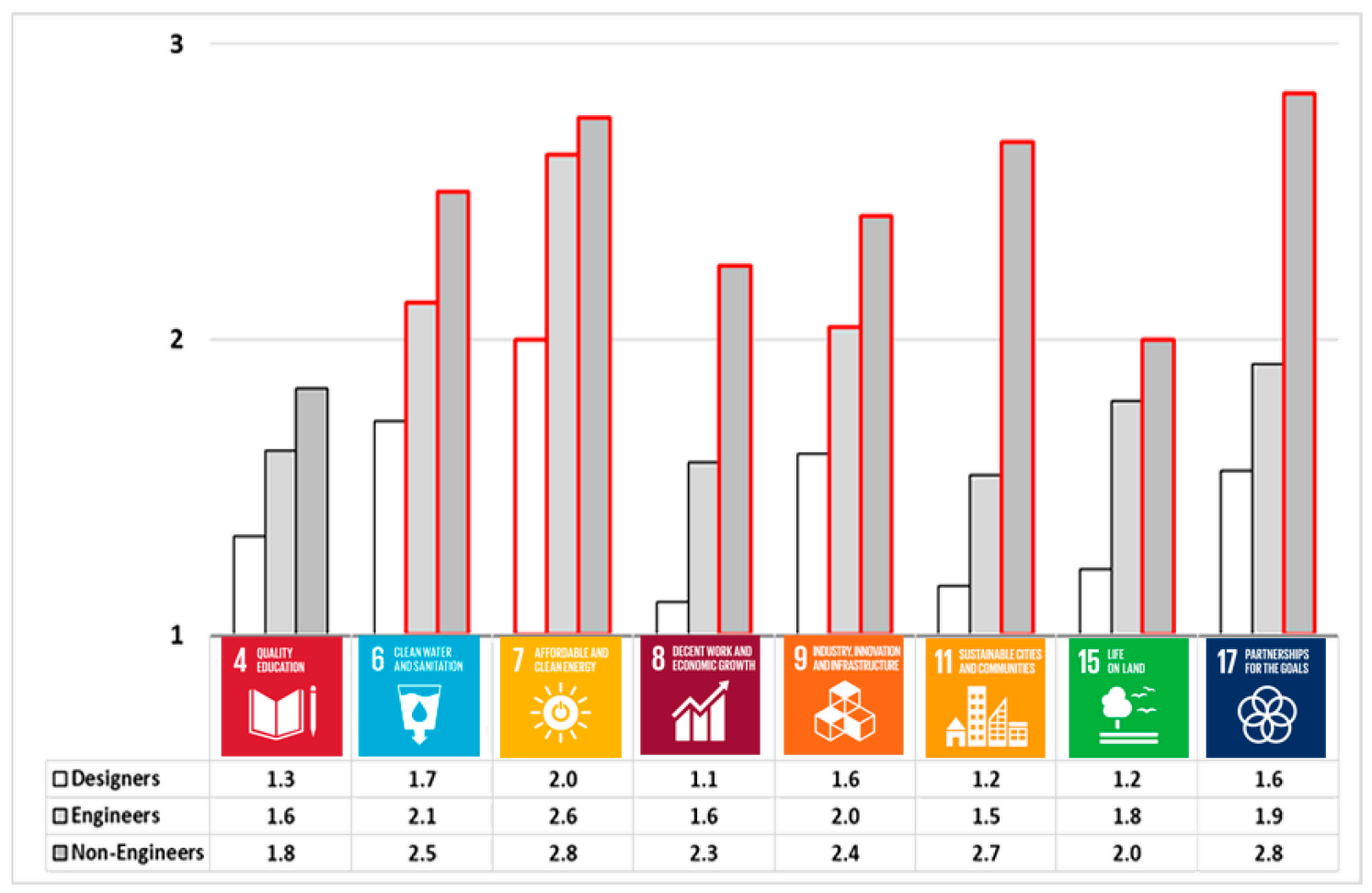

Figure 6. Compiled overall integration level assessment for the 8 selected SDGs as rated by each group of responders-red borders highlight the goals which were assessed by the team to have an integration level of 2 or above.

Axis based integration level assessment (4 SDGs)

When analyzing the results of the survey based on their distribution across the 3 axes of the map (Figure 1), the assessment reveals that most of the integration for the 4 SDGs (highlighted in grey in Figure 5) was achieved through the engineering axis. For SDG 6 the engineering integration was assessed to be 2.2; 2.6 for SDG 7; and 2.3 for SDG. However, for SDG 17 (partnership), the results indicated that the highest integration was achieved through the architectural axis-with an average of 2.1. Overall, the team evaluated that the least integration was achieved through the operation of the building. These details can be seen in Figure 7. When comparing the assessment of the 3 groups of responders, designers indicated that most of the integration was achieved through engineering and operation interventions. Non-designers rated the integration through engineering to be the highest. Finally, engineers 
indicated that the integration is more balanced across the 3 axes. The group-based assessment distributions are presented in Figures 8-10.

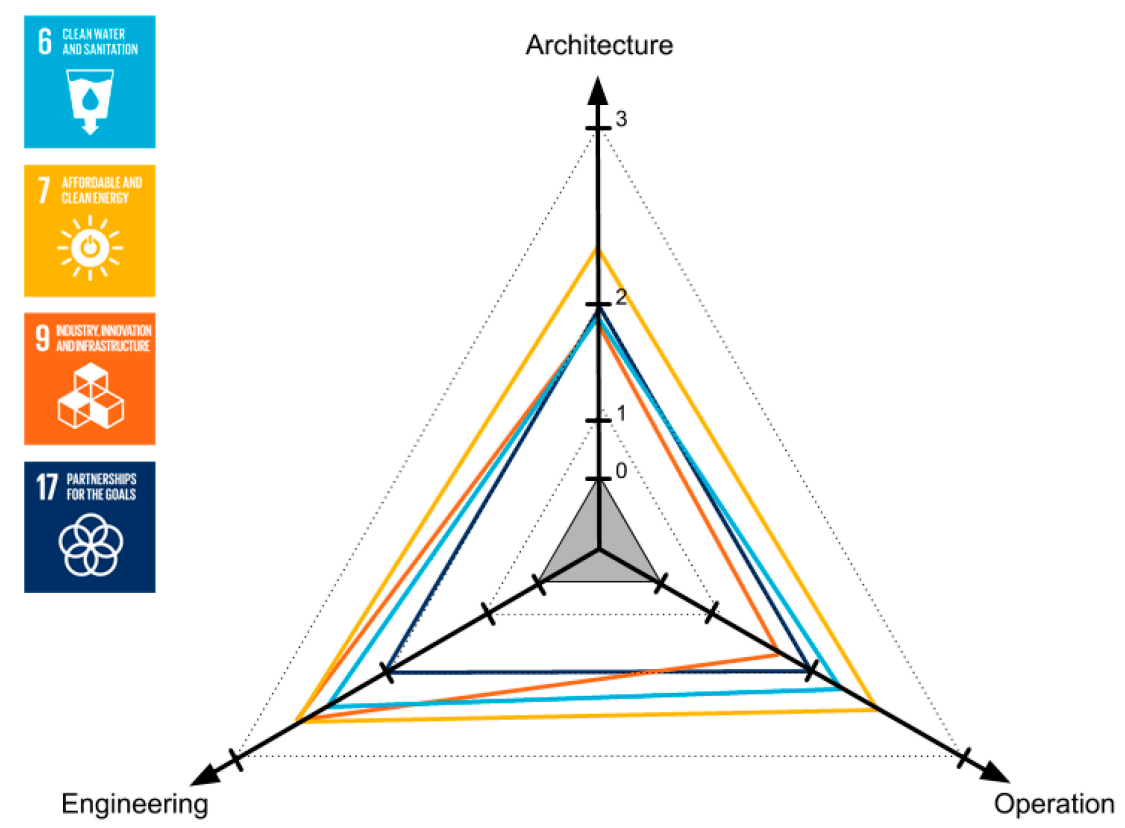

Figure 7. Assessment of the level of integration for of SDGs 6, 7, 9 and 17 across the 3 axes for the UQROP interpretation center.

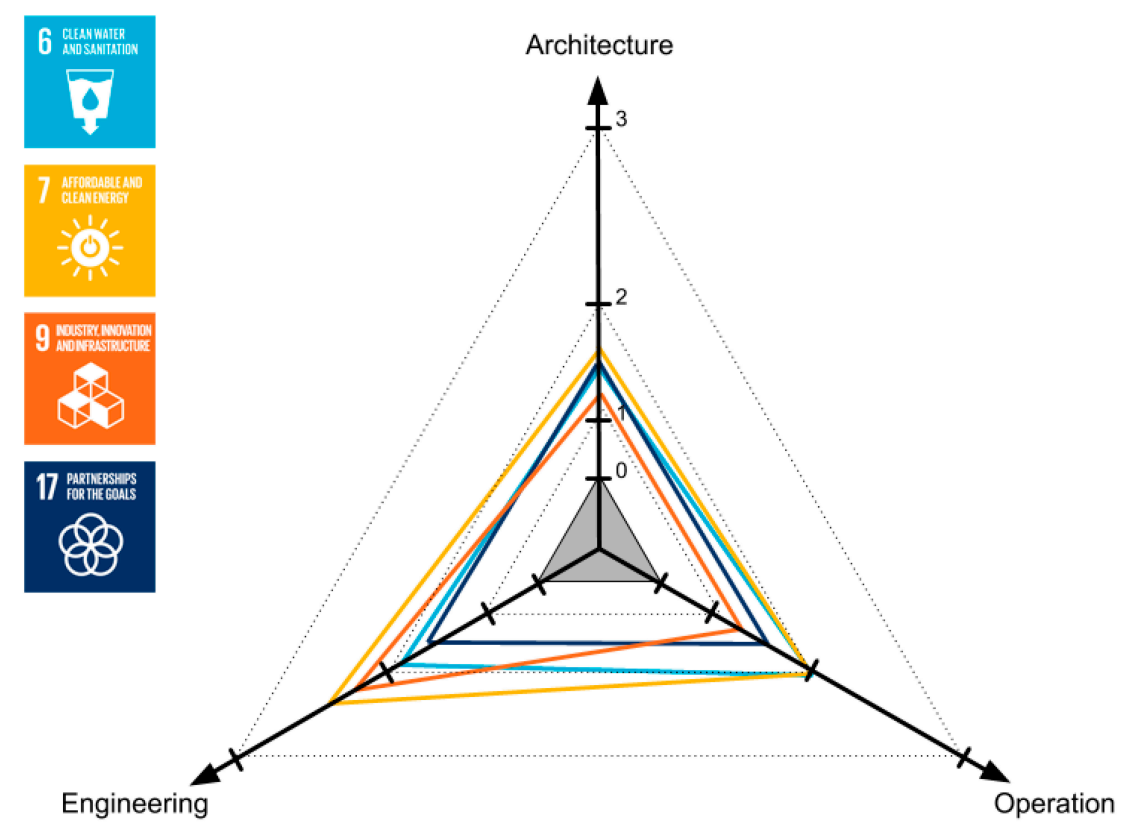

Figure 8. Designers' assessment of the integration level for SDGs 6, 7, 9 and 17 across the 3 axes for the UQROP interpretation center. 


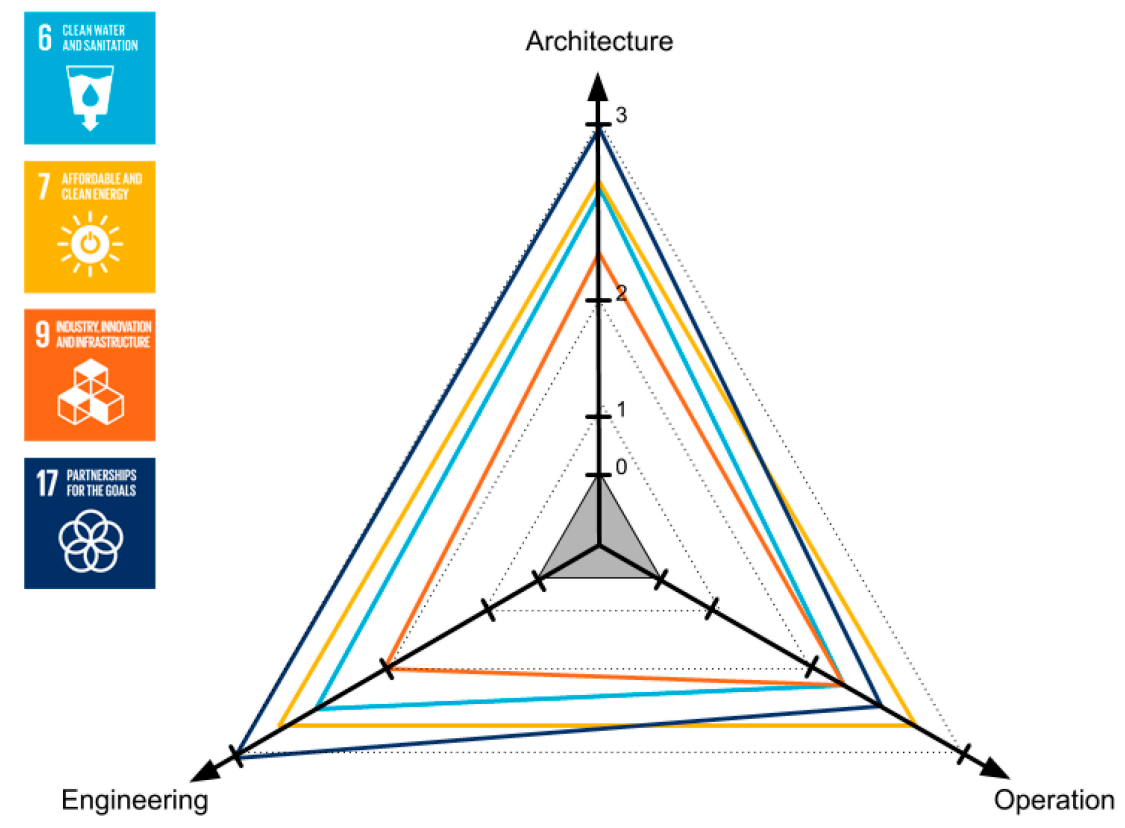

Figure 9. Engineers' assessment of the integration level for SDGs 6, 7, 9 and 17 across the 3 axes for the UQROP interpretation center.

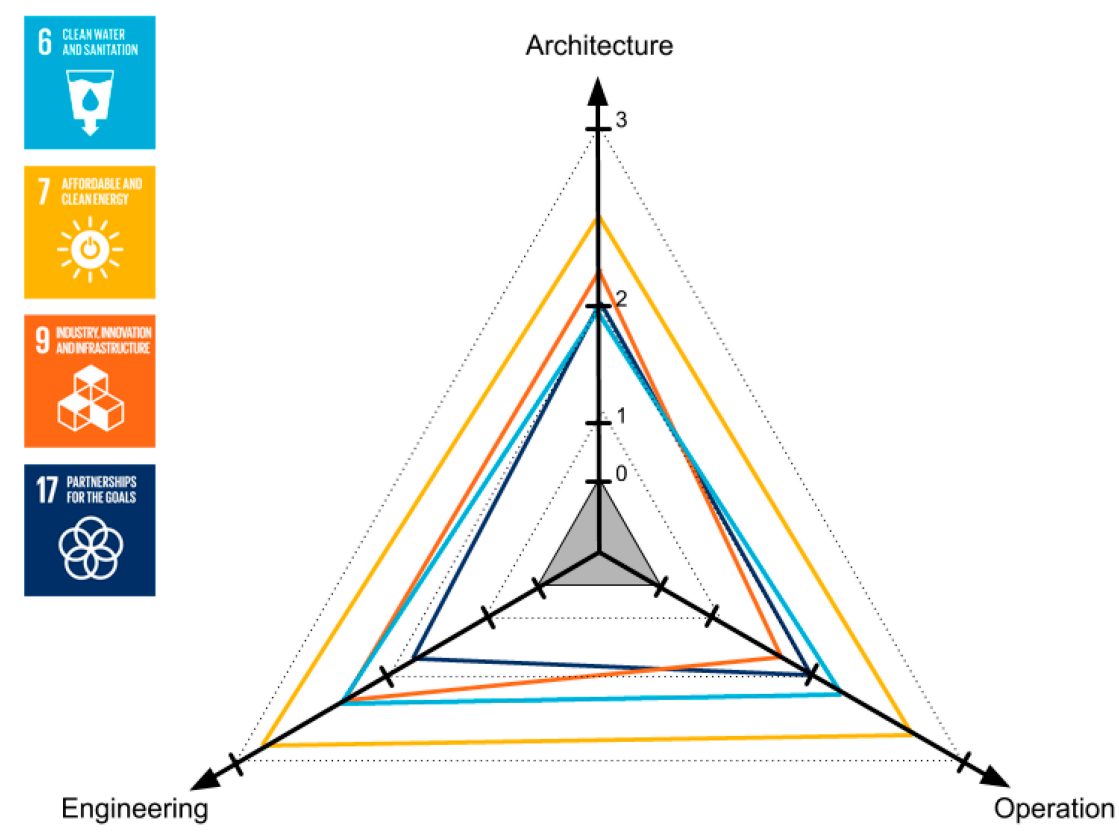

Figure 10. Non-designers' assessment of the integration level for SDGs 6, 7, 9 and 17 across the 3 axes for the UQROP interpretation center.

\section{Building Design Features and Sustainable Design Visions}

In order to identify the specific building design features and elements which contributed to the integration of the SDGs, the results of the survey were discussed during the team's charettes. Table 4 presents a list of the building-related features specific to each of the 8 SDGs selected. Additionally, Table 4 also presents the analysis of the dominant SDVs 
related to each of these 8 SDGs - which are mapped in Figure 11. Overall, most of the major design features were found to be technical, technological and product-focused. This focus was justified by the technical nature of the project-as a high-performance energy-positive construction. The overall approach for the project was found to be presenting a future driven vision in relation to the SDGs. As seen in Figure 11,3 of the 4 most integrated and 5 of the original 8 SDGs are within the future driven section of the map. However, a number of building features were found to be inspired by local traditions and history and were also focused on building positive human interactions. As seen in Figure 11, SDGs 4, 8, 15 and 17 are the main contributors to this approach. What is important to note, is that the building was found to have little or no design features which present future-driven human-focused or history-driven product-focused visions. The 4 most integrated SDGs (namely SDG 6, 7, 9 and 17), are presented in more details in the next section.

Table 4. Analysis summary for UQROP's building design features and SDVs in reference to the 8 selected SDGs-larger icons are used for the goals which were assessed to be most integrated into the project (level 2 and up).

\begin{tabular}{|c|c|c|}
\hline SDG & Building Design Features & SDVs \\
\hline 4 DUALCAIION & $\begin{array}{l}\text { - Veterinary clinic } \\
\text { - Discovery spaces for hands-on learning } \\
\text { - Multi-purpose rooms available for public } \\
\text { - Learning activities programmed in space } \\
\text { (regarding birds of prey, the site, the } \\
\text { environment, the town, and the building). } \\
\text { - Promoting traditional art and local artists }\end{array}$ & $\begin{array}{l}\text { Features are human-focused and are driven } \\
\text { by direct interactions with nature. The } \\
\text { features also are focused on the return to } \\
\text { nature and to active and more collective } \\
\text { modes of learning. That is both inspired by } \\
\text { history and dependent on some modern } \\
\text { tools. }\end{array}$ \\
\hline 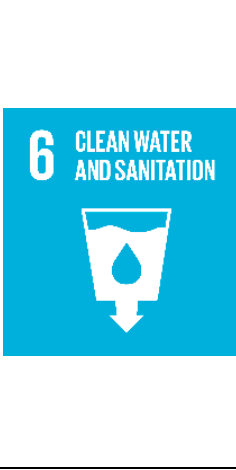 & $\begin{array}{l}\text { - Compostable toilets } \\
\text { - Low water usage equipment } \\
\text { - On-site tertiary wastewater treatment } \\
\text { - Reducing water demand through synergies } \\
\text { between site water management, geothermal, } \\
\text { fire-fighting requirements } \\
\text { - Stormwater collection and management } \\
\text { - Possibility for reusing greywater } \\
\text { - Native plants for irrigation water reduction }\end{array}$ & $\begin{array}{l}\text { Mainly product-focused and highly } \\
\text { dependent on equipment and technology. } \\
\text { The approach is driven by both history } \\
\text { (through the local and circular based } \\
\text { traditional models) and future (through the } \\
\text { use of new technologies). }\end{array}$ \\
\hline $\begin{array}{l}7 \text { AFFORDABIEAND } \\
\text { GLEANENEREY } \\
=0110= \\
=0\end{array}$ & $\begin{array}{l}\text { - Building-integrated photovoltaic thermal system } \\
\text { (BIPVT) } \\
\text { - Grid integration } \\
\text { - Direct expansion } \mathrm{CO}_{2} \text { geothermal system } \\
\text { - Predictive control system } \\
\text { - Supporting the research and development of } \\
\text { advanced energy systems in buildings }\end{array}$ & $\begin{array}{l}\text { The approach is highly product-focused with } \\
\text { the futuristic vision as the main driver. }\end{array}$ \\
\hline
\end{tabular}


Table 4. Cont.

\begin{tabular}{|c|c|c|}
\hline SDG & Building Design Features & SDVs \\
\hline 8 DEEENTWORKAND & $\begin{array}{l}\text { - Development of sustainable tourism - The } \\
\text { activities programmed in the spaces are in line } \\
\text { with sustainable tourism initiatives } \\
\text { - The exhibition spaces contribute to promoting } \\
\text { and building the local culture of Saint-Jude as } \\
\text { well as the natural heritage of Quebec } \\
\text { - Use of local timber for the construction }\end{array}$ & $\begin{array}{l}\text { The approach to the topic was found to } \\
\text { provide a balance between the human and } \\
\text { product/project vision. The design features } \\
\text { also aim at incorporating and reconnecting } \\
\text { with nature - making the approach slightly } \\
\text { more history driven. }\end{array}$ \\
\hline 9 NDUUSTRY,INDOUATION & $\begin{array}{l}\text { - Hybrid ventilation } \\
\text { - Integrated energy solutions-BIPVT and } \\
\text { predictive controls. } \\
\text { - The building aims to create a precedent and an } \\
\text { exemplar for innovation } \\
\text { - The building programming (tours, exhibits, } \\
\text { movie and other features) will present the } \\
\text { research and design of the building } \\
\text { - Integrating required site water management } \\
\text { with geothermal and fire-fighting requirements } \\
\text { in the same retention basin }\end{array}$ & $\begin{array}{l}\text { The approach to innovation is mainly } \\
\text { product-focused (with the exception of the } \\
\text { collaboration) and is driven by the desire to } \\
\text { present new possibilities for the future of } \\
\text { sustainability in buildings. }\end{array}$ \\
\hline & $\begin{array}{l}\text { - Reducing the footprint of the building on the } \\
\text { land through building form } \\
\text { - Reducing the carbon footprint-with low/zero } \\
\text { carbon target-through materials } \\
\text { - The expanded IDP adopted-setting a model for } \\
\text { collaboration } \\
\text { - Building systems with zero-emission targets } \\
\text { - Use of timber-allowing carbon sequestration } \\
\text { - Activities and programming are centred on the } \\
\text { protection of natural heritage }\end{array}$ & $\begin{array}{l}\text { The approach is mainly product-focused } \\
\text { with the goal to manage air quality, } \\
\text { emissions and waste. The building aims at } \\
\text { providing a future example to follow on the } \\
\text { topic. However, some human aspects (such } \\
\text { as collaboration) and some history driven } \\
\text { elements (such as the protection of natural } \\
\text { ecosystems) help balance the approach. }\end{array}$ \\
\hline & $\begin{array}{l}\text { - The building's operation is focused on the } \\
\text { protection and rehabilitation of birds of prey } \\
\text { - The veterinary clinic and the winter shelter aim } \\
\text { at ensuring the protection of the natural } \\
\text { ecosystem } \\
\text { - The building's placement on the site aims at } \\
\text { minimizing the damage to the natural ecosystem } \\
\text { - Ensuring any trees that are removed during } \\
\text { construction will be replanted }\end{array}$ & $\begin{array}{l}\text { The approach is highly focused on } \\
\text { protecting the natural ecosystem and } \\
\text { improving the bio-diversity-a history } \\
\text { driven vision for living in harmony with } \\
\text { nature (and specifically birds). The } \\
\text { approach-which is educational and hands- } \\
\text { on-is based on human interactions. Some } \\
\text { products and technologies are also } \\
\text { integrated. }\end{array}$ \\
\hline $\begin{array}{l}17 \text { PARTNERSHIIPS } \\
\text { FOR THE GOALS }\end{array}$ & $\begin{array}{l}\text { - An expanded futuristic IDP } \\
\text { - An effort to create a unique partnership focused } \\
\text { on innovation } \\
\text { - Collaborations between research, private and } \\
\text { public institutions } \\
\text { - Adoption of the SDGs in the early design phase }\end{array}$ & $\begin{array}{l}\text { The approach is mainly human-focused (to } \\
\text { create partnerships and collaborations). The } \\
\text { approach is also slightly future driven since } \\
\text { it tries to explore new ways IDP can } \\
\text { integrate students and non-practitioners. }\end{array}$ \\
\hline
\end{tabular}




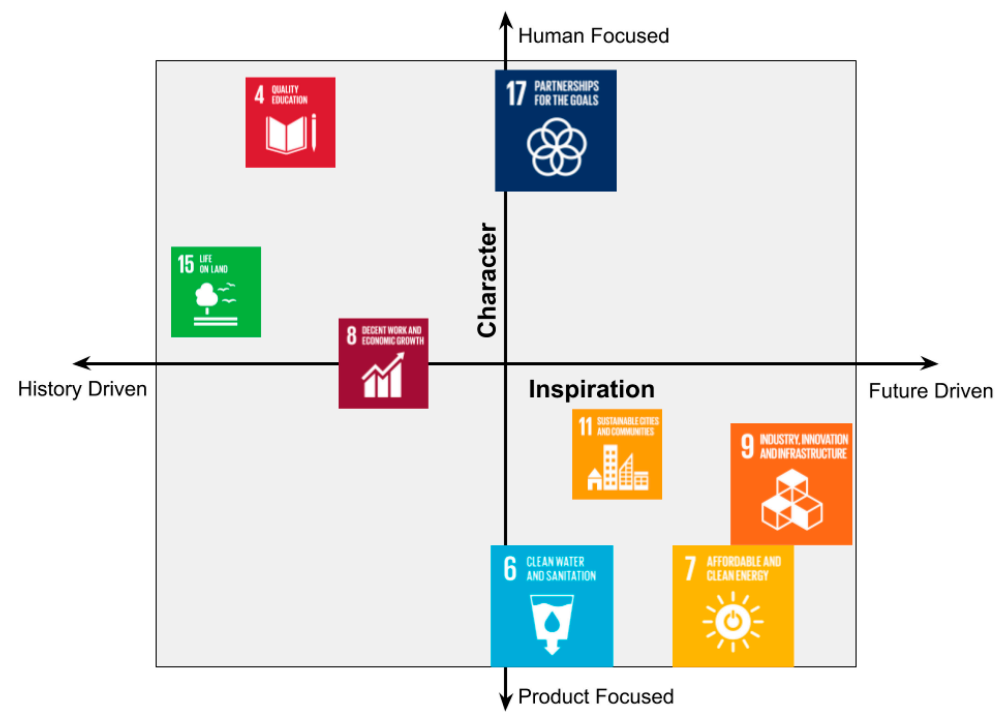

Figure 11. Analysis of the SDVs of the 8 SDGs for the UQROP project-larger icons are used for the goals which were assessed to be most integrated into the project (level 2 and up).

Energy was the topic that received most of the team's attention-in terms of both design effort and IDP discussion. SDG 7, which captured the topic of energy, was assessed to be highly integrated across all the 3 axes. A number of key building features relate to this topic. (A) Buildingintegrated photovoltaic thermal (BIPVT) system. The proposed system covers the entirety of the roof (Figure 4). The system aims to both generate electricity and capture useful thermal energy for space and domestic water heating. Although the technology is still considered new, a number of team members have already developed recognized expertise in the field (Researchers on the team have worked on three pioneering BIPVT projects: the Écoterra net-zero energy house (Eastman, QC), the John Molson School of Business building at Concordia University (Montreal, QC), and the Bibliothèque de Varennes (Varennes, QC)[124]). (B) Grid integration. The electric generation system will also be complemented with grid integration to manage the excess energy produced. (C) Direct expansion $\mathrm{CO} 2$ geothermal system. The center will be one of the first institutional buildings to incorporate this recent which is up to $25 \%$ more efficient than a conventional geothermal system and also occupies $20-40 \%$ less space. The space savings is key for minimizing the damage to the site. (D) Predictive controls. The application of predictive controls-for energy demand and consumption optimization-in early design is a new approach being researched in this project. Although most of the building design features are mainly engineering-driven, their application required deep integration and collaboration in both the operation and design axes.

For the water and sanitation goal (SDG 6), the highest integration was assessed to be achieved through engineering and operation and was realized by a number of key features. A) Composting toilets. One of the first application of composting toilets in an institutional building in Quebec. This required devising a system that fits the intuitional nature of the 
project, and solving some architectural, engineering, and operational issues. The UQROP plans to use the compost generated for landscaping purposes. B) Synergies between site waste management, geothermal and firefighting requirements. To reduce water demand and waste the team explored key synergies between the water storage systems in the project to strategically use them for heat storage.

For SDG 17, the team cited the unique project's IDP as the key for the partnership topic. The project is one of the first buildings to fully integrate practitioners, researchers, students and affiliates to government research agencies (private-academic-public partnership-non-governmental organization) within the integrated design team. Additionally, the expanded team membership in the schematic phase was also a key for setting a model for collaborative design effort for future high-performance buildings. The coherence in the design team-positively geared toward innovation and meaningful engagement-was also cited as a unique element in this project. Finally, for the topics of innovation and infrastructure sustainable development goal (SDG 9), the team mainly cited the integrated energy solutions (including the features covered in the water and energy and the links between them) as the key innovation in the project. Additionally, hybrid ventilation along with the activities and programming of the building (i.e., educational activities and installations) were cited as key innovations.

\section{Discussion}

The findings of this research provide important insights regarding the potential application of the 2030 agenda in the design of buildings. Specifically, the case of the UQROP illustrates the potential for the integration of at least 8 SDGs and the deep integration of 4 SDGs in the predesign phase of the project. The mapping of the SDVs (presented in Figure 11) indicates the variety of design approaches which were used to address these goals. It is important to note that the qualitative tool and assessment proposed (through the two maps presented in this research) do not aim to replace formal quantitative assessment methods available for the building sector (such as credit-based tools, energy codes, green building standards) or the tourism industry (such as those provided by the world tourism organization or the global sustainable tourism council). These quantitative tools could and should be used by design teams while considering the synergies between their criteria and the SDGs. Additionally, consultants for sustainable tourism and environmental tourism practices could be included in the subsequent phases of the project in order to optimize and improve the practices of the UQROP.

When comparing the methodology and results presented in this paper with the available research and literature, two key differences appear.

(1) The available literature which explores the links between sustainable (or green) buildings and the SDGs use the current building practices and rating systems as the basis of their analysis [23,24]. Alawneh 
et al. were able to find that the current practices and criteria in the design of non-residential buildings-through quantitative indicators-can contribute to the SDGs; they specifically found direct links to 9 of the 17 SDGs (Table 5 compares their findings with the connections made to the UQROP case). What is important to highlight, however, is that the 8 SDGs selected for the UQROP case intersect with the ones proposed by Alawneh et al. [23,24] and the World Green Building Council [125]-with the exception of SDG 4. However, and in spite of the similarity in findings, the main difference between this research and other available research lies in the approach followed. As illustrated by Wackernagel [126] in the case of the SDG index, the SDG indicators with available data do not encompass all the topics of the agenda and leave some of the most urgent problems unaddressed. The qualitative approach proposed in the paper (through the 2 analytical maps) uses the SDGs as its underpinning and is focused on deeply incorporating the agenda in the design process-rather than using it as a method for assessment. This approach enables building designers to openly discuss and integrate the SDGs and to analyze the potential connections and synergies between their buildings and the SDGs [26] in the early design phases (i.e., the ideation and pre-schematic phase). It also removes the risk of credit optimization approaches to the 2030 Agendawhich are commonly used with available building certifications [30,48,127]. Said otherwise, connecting available building assessment criteria with the SDGs would mean that all projects addressing those common criteria are also addressing the SDGs-even if unintentionally. The tools proposed in this research aim to raise awareness around the 2030 Agenda-its topics and targets-and to address the agenda through innovation. It is important to note that Alawneh et al.'s [23,24] method and findings, which are highly centred on measurable indicators and existing credit criteria, can be used in later project phases (i.e., following the schematic phase) to quantify the contribution of the building to the selected SDGs. However, it is important to note that based on the 4 levels of integration proposed in this research only targeting LEED credits requirements (as proposed in [24]) would result in a level 1 integration of the goals.

(2) Comparing the previous research findings regarding the contribution of buildings to the SDGs with the potential links presented in Appendix 1 shows that many goals remain unexplored. Other research, which focused on healthcare, energy and even urban ecosystems, was able to explore the relations between these particular sectors and the 2030 Agenda on a comprehensive level. Common to their findings is the broad connections, synergies and trade-offs across all the 17 SDGs-highlighting the potential of each sector, strategy, project or plan to address any of the goals $[12,71,75,128,129]$. The design questions and links presented in Appendix 1 could be used as a starting point for researchers to explore the broad interactions and synergies between construction and the 2030 agenda. 
Table 5. Comparing the connections and contributions of buildings to the SDGs proposed in this research and in examples from other references.

\begin{tabular}{|c|c|c|c|c|c|c|c|c|c|c|c|c|c|c|c|c|c|}
\hline & \multicolumn{17}{|c|}{ SDGs } \\
\hline Reference & 1 & 2 & 3 & 4 & 5 & 6 & 7 & 8 & 9 & 10 & 11 & 12 & 13 & 14 & 15 & 16 & 17 \\
\hline Alawneh et al. $[23,24]$ & & & Q & & & 口 & Q & 0 & 0 & & Q & Q & 0 & & Q & & \\
\hline WGBC * [125] & & & 문 & & & & 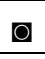 & 0 & 口 & & ㅁ & 口 & ㅁ & & Q & & ㅁ \\
\hline UQROP Case & & & & 0 & & 0 & Q & a & 0 & & 0 & & & & Q & & 0 \\
\hline Potential links ** & 0 & ס & 0 & 0 & 0 & 0 & Q & 0 & Q & व & Q & o & व & 0 & o & a & 0 \\
\hline
\end{tabular}

* World Green Building Council; ** As presented in Appendix A1.

\section{LIMITATIONS AND FUTURE RESEARCH}

This study presents several limitations due to (1) the assumptions used in the development of the analysis maps; (2) the methods deployed, and (3) the specific characteristics of the case study used. One of the assumptions used in the study is the disconnect of the current planning and design process from the sustainable development objectives. Although the current prevailing practices do consider certain environmental, social and economic factors in the design, the researchers were unable to find theoretical or practical models which have sustainable development, in its broad definition, as their core objective (as opposed to cost, energy, or sustainability credits optimization objectives) - this assumption is supported by the work of [43,51,58-64]. Additionally, this research does not explicitly compare, analyze or map the interaction between these rating and certification tools and the SDGs-thus not highlighting the possible synergies between the 2030 Agenda and the green building rating tools. Authors assumed the familiarity of building design teams with the specific systems and codes they wish to implement and considered this mapping beyond the scope of this paper. The methods of this research also present a number of limitations. Due to the specific nature of the case study (i.e., focused on the early design phase of the project) and the composition of the integrated design team (i.e., made of a group with dissimilar expertise between students and practitioners, and roles between designers and researchers), this research only used one survey and collective group discussions as a mean for gathering and validating data. This method results in limitation due to the divergence in the data collected. It also limits the validity of the results to the specific case studied. However, it is important to note that the case study is mainly utilized to test the applicability of the proposed methodology in a real-life context in order to help guide practitioners in its implementation and to present its visual outcomes. The number of responders-which constituted all the design team excluding the authors-was beyond the control of the authors. The responses of the UQROP design team regarding the level of integration of the SDGs in the project are not globally applicable ratings and do not constitute an exhaustive best practice reference guide. While the restrictions on the validity of the results beyond the specific project might be seen as a limitation, the collective discussion revealed that the 
differences in the assessment to be important in improving the design in subsequent phases.

Future research should focus on exploring the tools required to incorporate the 2030 Agenda at the different design phases of projectsincluding the post-occupancy phase-by soliciting assessments from the users of buildings which integrated the SDGs in their design. Future research should overcome some of the limitations reported in this study by providing clear examples or references that can help the design team members in the assessment process. Additionally, practitioners and design teams should utilize the maps proposed in this paper to analyze building projects with different goals and missions-such as projects that have clear social or cultural missions or that have a community development focus. Additionally, by reassessing the integration of the SDGs achieved through some of the approaches used in the UQROP project (such as the BIPVT system or synergies in water storage and demand) potential integration level benchmarks could be established for different building elements. This future analysis and research, which would use methods to validate data across multiple case studies (such as the Delphi method), could help identify new building design features that are specifically relevant to each of the 17 different SDG. In turn, a practical reference for SDGs building design can be compiled and made available. Additionally, another line of research should focus on mapping and clarifying the direct and indirect links between the SDGs and the mainstream certification, assessment tools and green building codes globally. Finally, the possible application of the SDVs map could be explored beyond the building IDP; its use could be tested in the analysis of projects in the context of design competition on the local, national or international levels [130-132]; and in the development of strategies or plans at the institutional level [12].

\section{CONCLUSIONS}

With the rise of the 2030 Agenda as a unifying framework for sustainability, the building sector has been struggling to fully incorporate its goals and targets. Based on the review of the recent literature, the current incorporation challenges were traced back to the focus on existing environmental assessment criteria rather than on the possible synergies between buildings the SDGs. The integrated design process, which has become common in sustainable building projects, was perceived as the most appropriate setting for addressing these gaps. This paper developed and tested mapping tools which analyze (1) the integration of SDGs in building projects, and (2) the design approaches to the SDG topics-named sustainable design visions (SDVs). The first tool was designed based on the distinction between the architectural, engineering and operational concerns, which is seen in the IDP literature [25,26], and on the need to distinguish between meeting already established criteria (i.e., standardbased) and innovative approaches [12]. The second tool was constructed based on the work of Fry, Fisher and Boutinet [105,111,112] and aims to 
assess the character of the design approach (between product and humanfocused) and its inspiration (history vs future driven). In order to further facilitate the integration and use of the 2030 Agenda in building design, a comprehensive list of the 17 SDGs was created which incorporates design questions and presents building-specific elements extracted from the 2030 Agenda. Additionally, an overall process for the use of these two tools was proposed.

To test the applicability of these tools in building projects, the new UQROP bird interpretation center in Saint-Jude Quebec was used as a case study. This new building aims at being state-of-the-art energy positive and low carbon facility which will host activities focused on natural heritage protection and sustainability education. The researchers were directly involved in the project within an expanded integrated design team made of more than 20 researchers, students and practitioners. For the UQROP case, 8 of the 17 SDGs were identified as relevant topics of focus. With the help of a survey, the design team rated the integration of the 8 goals to be above 1 -indicating a move beyond current standards. Through the openended comments and collective discussion in the design charrettes, the specific building design features for each of the 8 goals were identified. The design visions regarding the project's highly integrated SDGs were found to be mainly product and technology-focused and future driven. When comparing the methods and findings of this paper with the available literature, it was clear that they are better geared towards the ideation and early design phases of building projects. Additionally, the approach to the SDGs proposed in this research echoed that which was used by researchers outside the field of construction and buildings [12,71,75,128,129].

This paper aims to bridge integrated building design with the broader sustainable development goals as presented in the agenda 2030 of the United Nations [15]. To achieve this, the SDGs were localized to the specific project and building design features level. This research and the analytical tools it presents bring forth important insights for architects and design teams regarding the use of SDGs as a framework for integrating and analyzing the sustainability in buildings. This research contributes directly to the theory and practice of sustainable building design and construction by presenting insights into the possible local and case-specific applications of the 2030 Agenda. The research also provides important practical tools that could inform private and public building design and construction practices.

\section{AUTHOR CONTRIBUTIONS}

SG conducted the literature review, developed the methodology and designed the mapping tools. SG and CC contributed equally to the application of the methodology in the case study. SG analyzed the data. SG wrote the paper with input and guidance from CC. 


\section{CONFLICTS OF INTEREST}

The authors declare that there is no conflict of interest.

\section{ACKNOWLEDGMENTS}

The authors would like to thank Dr. Bruno Lee, Gilles Jean and the researchers from the Center for Zero Energy Building Studies (CZEBS) for leading and coordinating the integrated design process for the case presented. The authors would also like to sincerely thank the Union Québécoise de Réhabilitation des Oiseaux de Proie (UQROP) for their support, and all the project's integrated design team for their positive collaboration and engagement. Goubran would like to acknowledge the support received by the Social Sciences and Humanities Research Council through the Vanier Canada Graduate Scholarship program as well as the support received through Concordia University, its School of Graduate Studies and Individualized Program. Cucuzzella would like to acknowledge the support received through the Social Sciences and Humanities Research Council of Canada (SSHRC) and the Concordia University Research Chair program.

Appendix A1. Goals, design questions and elements of focus-adapted from and based on [14,15,117,118].

\begin{tabular}{|c|c|c|}
\hline Sustainable Development Goal & Building design question & Building-related elements \\
\hline $\begin{array}{l}\text { Goal 1. End poverty in all its forms } \\
\text { everywhere }\end{array}$ & $\begin{array}{l}\text { How does the project } \\
\text { contribute to ending poverty? }\end{array}$ & $\begin{array}{l}\text { - Control over land and resources } \\
\text { - Resilience to climate-related events and natural disaster }\end{array}$ \\
\hline $\begin{array}{l}\text { Goal 2. End hunger, achieve food } \\
\text { security and improved nutrition } \\
\text { and promote sustainable } \\
\text { agriculture }\end{array}$ & $\begin{array}{l}\text { How does the project } \\
\text { contribute to ending hunger, } \\
\text { or providing food security, } \\
\text { nutrition and sustainable } \\
\text { agriculture? }\end{array}$ & $\begin{array}{l}\text { - Access to food } \\
\text { - Small scale food production } \\
\text { - Food security } \\
\text { - Climate adaptation }\end{array}$ \\
\hline $\begin{array}{l}\text { Goal 3. Ensure healthy lives and } \\
\text { promote well-being for all at all } \\
\text { ages }\end{array}$ & $\begin{array}{l}\text { How does the project } \\
\text { contribute to health and well- } \\
\text { being? }\end{array}$ & $\begin{array}{l}\text { - Access to health facilities } \\
\text { - Mental health and well-being } \\
\text { - air, water, soil pollution } \\
\text { - contamination control }\end{array}$ \\
\hline $\begin{array}{l}\text { Goal 4. Ensure inclusive and } \\
\text { equitable quality education and } \\
\text { promote lifelong learning } \\
\text { opportunities for all }\end{array}$ & $\begin{array}{l}\text { How does the project } \\
\text { contribute to education and } \\
\text { lifelong learning? }\end{array}$ & $\begin{array}{l}\text { - Skill building } \\
\text { - Hands-on sustainability learning opportunities } \\
\text { - vocational training } \\
\text { - Diversity, inclusion, and equality } \\
\text { - Accessibility for building and individual educational } \\
\text { spaces } \\
\text { - Building capacity for using communication and } \\
\text { information technologies } \\
\text { - Indigenous knowledge }\end{array}$ \\
\hline $\begin{array}{l}\text { Goal 5. Achieve gender equality } \\
\text { and empower all women and girls }\end{array}$ & $\begin{array}{l}\text { How does the project advance } \\
\text { gender equality and } \\
\text { empowerment? }\end{array}$ & $\begin{array}{l}\text { - Safe environments } \\
\text { - Participation of women in leadership } \\
\text { - Access to resources, and education } \\
\text { - use of technologies }\end{array}$ \\
\hline
\end{tabular}


Appendix A1. Cont.

\begin{tabular}{|c|c|c|}
\hline Sustainable Development Goal & Building design question & Building-related elements \\
\hline $\begin{array}{l}\text { Goal } 6 \text {. Ensure availability and } \\
\text { sustainable management of water } \\
\text { and sanitation for all }\end{array}$ & $\begin{array}{l}\text { How does the project } \\
\text { contribute to sustainable } \\
\text { water management and } \\
\text { sanitation? }\end{array}$ & $\begin{array}{l}\text { - Reduction of wastewater } \\
\text { - Capturing rain and stormwater } \\
\text { - Recycling and reusing greywater } \\
\text { - Eliminating hazardous dumping } \\
\text { - Water use efficiency } \\
\text { - Water management systems } \\
\text { - Protect and restore water ecosystems } \\
\text { - Sanitation management }\end{array}$ \\
\hline $\begin{array}{l}\text { Goal 8. Promote sustained, } \\
\text { inclusive and sustainable } \\
\text { economic growth, full and } \\
\text { productive employment and } \\
\text { decent work for all }\end{array}$ & $\begin{array}{l}\text { How does the project help in } \\
\text { achieving sustainable growth } \\
\text { and inclusion and promote } \\
\text { employment? }\end{array}$ & $\begin{array}{l}\text { - Sustainable tourism } \\
\text { - Promotion of local culture } \\
\text { - Work/job creation } \\
\text { - Equal access to jobs and training } \\
\text { - Work insertion } \\
\text { - Resource efficiency }\end{array}$ \\
\hline $\begin{array}{l}\text { Goal 9. Build resilient } \\
\text { infrastructure, promote inclusive } \\
\text { and sustainable industrialization } \\
\text { and foster innovation }\end{array}$ & $\begin{array}{l}\text { How does the project } \\
\text { contribute to innovation? }\end{array}$ & $\begin{array}{l}\text { - Innovation in design } \\
\text { - Technology integration } \\
\text { - Scientific and design research } \\
\text { - Retrofitting } \\
\text { - Environmental and sustainable technologies }\end{array}$ \\
\hline $\begin{array}{l}\text { Goal } 10 . \text { Reduce inequality within } \\
\text { and among countries }\end{array}$ & $\begin{array}{l}\text { How does the project help } \\
\text { reduce inequality? }\end{array}$ & $\begin{array}{l}\text { - Policies for inclusion } \\
\text { - Non-gender bias or socio-economic class spaces } \\
\text { - Non-discriminatory access }\end{array}$ \\
\hline $\begin{array}{l}\text { Goal 11. Make cities and human } \\
\text { settlements inclusive, safe, } \\
\text { resilient and sustainable }\end{array}$ & $\begin{array}{l}\text { How does the project improve } \\
\text { the resilience, safety and } \\
\text { sustainability of urban } \\
\text { settlements? }\end{array}$ & $\begin{array}{l}\text { - Protection of cultural and natural heritage } \\
\text { - Air quality } \\
\text { - Waste management } \\
\text { - Resource efficiency } \\
\text { - Disaster risk reduction } \\
\text { - Reduction of the human footprint } \\
\text { - Reduction of emissions and waste } \\
\text { - Considerate urbanization } \\
\text { - Participatory and inclusive processes } \\
\text { - Mobility }\end{array}$ \\
\hline $\begin{array}{l}\text { Goal 12. Ensure sustainable } \\
\text { consumption and production } \\
\text { patterns }\end{array}$ & $\begin{array}{l}\text { How does the project promote } \\
\text { sustainable consumption and } \\
\text { production patterns? }\end{array}$ & $\begin{array}{l}\text { - Efficient use of natural resources } \\
\text { - Food waste } \\
\text { - Life cycle thinking } \\
\text { - Chemical control } \\
\text { - Procurement and sourcing } \\
\text { - Promoting local culture and sustainable tourism } \\
\text { - Minimizing impacts }\end{array}$ \\
\hline $\begin{array}{l}\text { Goal 13. Take urgent action to } \\
\text { combat climate change and its } \\
\text { impacts }\end{array}$ & $\begin{array}{l}\text { How does the project help in } \\
\text { the fight against climate } \\
\text { change? }\end{array}$ & $\begin{array}{l}\text { - Climate adaption and mitigation } \\
\text { - Reporting on emissions, climate risks and impacts } \\
\text { - Raise awareness on climate change and its risks }\end{array}$ \\
\hline
\end{tabular}


Appendix A1. Cont.

\begin{tabular}{|c|c|c|}
\hline Sustainable Development Goal & Building design question & Building-related elements \\
\hline $\begin{array}{l}\text { Goal } 14 \text {. Conserve and sustainably } \\
\text { use the oceans, seas and marine } \\
\text { resources for sustainable } \\
\text { development }\end{array}$ & $\begin{array}{l}\text { How does the project help in } \\
\text { sustaining water eco-systems? }\end{array}$ & $\begin{array}{l}\text { - Reduce marine pollution or waste that could reach waters } \\
\text { - protecting coastal ecosystems and sites }\end{array}$ \\
\hline $\begin{array}{l}\text { Goal 15. Protect, restore and } \\
\text { promote sustainable use of } \\
\text { terrestrial ecosystems, sustainably } \\
\text { manage forests, combat } \\
\text { desertification, and halt and } \\
\text { reverse land degradation and halt } \\
\text { biodiversity loss }\end{array}$ & $\begin{array}{l}\text { How does the project help in } \\
\text { protecting ecosystems and } \\
\text { biodiversity? }\end{array}$ & $\begin{array}{l}\text { - Protection of forests } \\
\text { - Reducing degradation of natural habitats } \\
\text { - Protect threatened species } \\
\text { - Raising awareness on illegal trafficking of wildlife } \\
\text { products } \\
\text { - Managing invasive species } \\
\text { - Protect biodiversity }\end{array}$ \\
\hline $\begin{array}{l}\text { Goal 16. Promote peaceful and } \\
\text { inclusive societies for sustainable } \\
\text { development, provide access to } \\
\text { justice for all and build effective, } \\
\text { accountable and inclusive } \\
\text { institutions at all levels }\end{array}$ & $\begin{array}{l}\text { How does the project promote } \\
\text { peace, justice and } \\
\text { accountability? }\end{array}$ & $\begin{array}{l}\text { - Creating safe spaces } \\
\text { - Integrated, collective, democratic and inclusive decision } \\
\text { making } \\
\text { - Access to information and knowledge }\end{array}$ \\
\hline $\begin{array}{l}\text { Goal 17. Strengthen the means of } \\
\text { implementation and revitalize the } \\
\text { Global Partnership for Sustainable } \\
\text { Development }\end{array}$ & $\begin{array}{l}\text { How does the advance } \\
\text { partnership? }\end{array}$ & $\begin{array}{l}\text { - Collaboration } \\
\text { - Promotion of sustainable technologies and process } \\
\text { - Public-private partnerships } \\
\text { - Partnerships with civil society } \\
\text { - Building momentum for progress for sustainable } \\
\text { development }\end{array}$ \\
\hline
\end{tabular}

\section{REFERENCES}

1. Doan DT, Ghaffarianhoseini A, Naismith N, Zhang T, Ghaffarianhoseini A, Tookey J. A critical comparison of green building rating systems. Build Environ. 2017;123:243-60.

2. Bernardi E, Carlucci S, Cornaro C, Bohne R. An Analysis of the Most Adopted Rating Systems for Assessing the Environmental Impact of Buildings. Sustainability. 2017;9(7):1226.

3. Díaz-López C, Carpio M, Martín-Morales M, Zamorano M. Analysis of the scientific evolution of sustainable building assessment methods. Sustain Cities Soc. 2019;49:101611.

4. Illankoon IMCS, Tam VWY, Le KN, Shen L. Key credit criteria among international green building rating tools. J Clean Prod. 2017;164:209-20.

5. Alyami SH, Rezgui Y. Sustainable building assessment tool development approach. Sustain Cities Soc. 2012;5(1):52-62.

6. Cole RJ. Building environmental assessment methods: redefining intentions and roles. Build Res Inf. 2005;33(5):455-67.

7. Brandon PS, Lombardi P. Evaluating Sustainable Development in the Built Environment. 2nd ed. Chichester (UK): Blackwell Publishing Ltd; 2011. 
8. Cucuzzella C. Why is fourth generation evaluation essential for sustainable design? Des Princ Pract. 2011;5(1):239-51.

9. Gibberd J. Measuring capability for sustainability: the Built Environment Sustainability Tool (BEST). Build Res Inf. 2015;43(1):49-61.

10. Eizenberg E, Jabareen Y. Social Sustainability: A New Conceptual Framework. Sustainability. 2017;9(1):68.

11. Pedersen CS. The UN Sustainable Development Goals (SDGs) are a Great Gift to Business! Procedia CIRP. 2018;69:21-4.

12. Villeneuve C, Tremblay D, Riffon O, Lanmafankpotin G, Bouchard S. A Systemic Tool and Process for Sustainability Assessment. Sustainability. 2017;9(10):1909.

13. Wysokińska Z. Millenium Development Goals/UN and Sustainable Development Goals/UN as Instruments for Realising Sustainable Development Concept in the Global Economy. Comp Econ Res. 2017;20(1): 101-18.

14. United Nations. The Future We Want. Our Common Vision. New York (US): United Nations; 2012.

15. United Nations. Transforming our world: The 2030 agenda for sustainable development. New York (US): United Nations; 2015.

16. Diaz-Sarachaga JM, Jato-Espino D, Castro-Fresno D. Is the Sustainable Development Goals (SDG) index an adequate framework to measure the progress of the 2030 Agenda? Sustain Dev. 2018. doi: 10.1002/sd.1735

17. Jayasooria D. Sustainable Development Goals and Social Work: Opportunities and Challenges for Social Work Practice in Malaysia. J Hum Rights Soc Work. 2016;1(1):19-29.

18. Allen C, Metternicht G, Wiedmann T. Initial progress in implementing the Sustainable Development Goals (SDGs): a review of evidence from countries. Sustain Sci. 2018;13(5):1453-67.

19. United Nations. Annex: Global Indicator Framework for the Sustainable Development Goals and Targets of the 2030 Agenda for Sustainable Development. In: Work of the Statistical Commission pertaining to the 2030 Agenda for Sustainable Development. New York (US): UN General Assembly; 2017.

20. Ni C, de Souza R, Lu Q, Goh M. Emergency Preparedness of Humanitarian Organizations: A System Dynamics Approach. In: Klumpp M, de Leeuw S, Regattieri A, de Souza R, editors. Humanitarian Logistics and Sustainability. Cham (Switzerland): Springer International Publishing Switzerland; 2015. p. 113-27.

21. Roetzel A, Fuller R, Rajagopalan P. Integral sustainable design-Reflections on the theory and practice from a case study. Sustain Cities Soc. 2017;28:225-32.

22. Gusmão Caiado RG, Leal Filho W, Quelhas OLG, Luiz de Mattos Nascimento D, Ávila LV. A literature-based review on potentials and constraints in the implementation of the sustainable development goals. J Clean Prod. 2018;198:1276-88.

23. Alawneh R, Ghazali F, Ali H, Sadullah AF. A Novel framework for integrating United Nations Sustainable Development Goals into sustainable non- 
residential building assessment and management in Jordan. Sustain Cities Soc. 2019;49:101612.

24. Alawneh R, Mohamed Ghazali FE, Ali H, Asif M. Assessing the contribution of water and energy efficiency in green buildings to achieve United Nations Sustainable Development Goals in Jordan. Build Environ. 2018;146:119-32.

25. The Institute for Market Transformation to Sustainability (MTS). Integrative Process (IP). ANSI Consensus Standard Guide 2.0 for Design and Construction of Sustainable Buildings and Communities. Washington (US): ANSI; 2012.

26. Busby Perkins+Will; Stantec Consulting. Roadmap for the Integrated Design Process. Vancouver (Canada): BC Green Building Roundtable; 2007.

27. Ehrenfeld JR. Sustainability by Design: A Subversive Strategy for Transforming Our Consumer Culture. New Haven (US): Yale University Press; 2009.

28. Tabb PJ, Deviren AS. The greening of architecture: A critical history and survey of contemporary sustainable architecture and urban design. Farnham (UK): Ashgate Publishing Limited; 2014.

29. Zuo J, Zhao ZY. Green building research-current status and future agenda: A review. Renew Sustain Energy Rev. 2014;30:271-81.

30. Goubran S, Emond G, Cucuzzella C. Understanding Regional Sustainability in the Built Environment. Presented at: The 2nd ARTEM Organisational Creativity and Sustainability International Conference; 2017 Sep 14-16; Nancy, France.

31. Jiang W, Gowri K, Lane M, Thornton B, Liu B. Technical Support Document: 50\% Energy Savings Design Technology Packages for Highway Lodging Buildings. Richland (US): Pacific Northwest National Laboratory; 2009. Report No.: PNNL-18773.

32. Eichholtz P, Kok N, Quigley J. Doing well by doing good? Green office buildings. Am Econ Rev. 2010;100:2494-511.

33. Jones SA, Laquidara-Carr D, editors. World Green Building Trends 2016Developing Markets Accelerate Global Green Growth. Bedford (US): Dodge Data \& Analytics, 2016.

34. Murray B, Rivers N. British Columbia’s revenue-neutral carbon tax: A review of the latest 'grand experiment' in environmental policy. Energy Policy. 2015;86:674-83.

35. Brouwer J, Mulder A, Spuybroek L. Vital beauty: reclaiming aesthetics in the tangle of technology and nature. Rotterdam (Netherlands): V2 Pub./NAi; 2012.

36. Hosey L. The shape of green: aesthetics, ecology, and design. Washington (US): Island Press; 2012.

37. DeKay M. Integral Sustainable Design. London (UK): Earthscan Publications; 2011.

38. Cole RJ, Lorch R, editors. Buildings Culture and Environment-Informing Local and Global Practices. Oxford (UK): Blackwell Publishing; 2003.

39. Gupta J, Vegelin C. Sustainable development goals and inclusive development. Int Environ Agreements Polit Law Econ. 2016;16(3):433-48. 
40. Government of Canada. Canada's Implementation of the 2030 Agenda for Sustainable Development-Voluntary National Review. Ottawa (Canada): Government of Canada; 2018.

41. Cucuzzella C. Is Sustainability Reorienting the Visual Expression of Architecture? RACAR Rev d'art Can. 2015;40(2):86.

42. Giddens A. The Constitution of Society. Berkeley (US): University of California Press; 1984.

43. Arroyo P. Exploring Decision-Making Methods for Sustainable Design in Commercial Buildings. Berkeley (US): University of California; 2014.

44. Boyko CT, Gaterell MR, Barber ARG, Brown J, Bryson JR, Butler D, et al. Benchmarking sustainability in cities: The role of indicators and future scenarios. Glob Environ Chang. 2012;22(1):245-54.

45. Kylili A, Fokaides PA, Jimenez PAL. Key Performance Indicators (KPIs) approach in buildings renovation for the sustainability of the built environment: A review. Renew Sustain Energy Rev. 2016;56:906-15.

46. Ade R, Rehm M. The unwritten history of green building rating tools: a personal view from some of the 'founding fathers'. Build Res Inf. 2019. doi: 10.1080/09613218.2019.1627179

47. Markovich J, D’Angelo MS, Dinh T. Community Wellbeing. A Framework for the Canadian Design Professions. Ottawa (Canada): The Conference Board of Canada; 2018.

48. Cucuzzella C. The limits of current evaluation methods in a context of sustainable design: prudence as a new framework. Int J Des Eng. 2009;2(3):243-61.

49. Jones SA, Laquidara-Carr D. editots. World Green Building Trends 2018Smart market report. Smart Market Report. Bedford (US): Dodge Data \& Analytics; 2018. p. 80.

50. Mattoni B, Guattari C, Evangelisti L, Bisegna F, Gori P, Asdrubali F. Critical review and methodological approach to evaluate the differences among international green building rating tools. Renew Sustain Energy Rev. 2018;82:950-60.

51. Ding GKC. Sustainable construction-The role of environmental assessment tools. J Environ Manage. 2008;86(3):451-64.

52. Bragança L, Mateus R, Koukkari H. Building sustainability assessment. Sustainability. 2010;2(7):2010-23.

53. Berardi U. Beyond Sustainability Assessment Systems: Upgrading Topics by Enlarging The Scale of Assessment. Int J Sustain Build Technol Urban Dev. 2012;2(4):276-82.

54. Schmidt O, Jayson P. Towards a Greener Future-DLA Piper's market report on sustainable real estate. London (UK): DLA Piper; 2014.

55. Bernstein HM, Russo MA, Fitch E, Laquidara-Carr D, editors. World Green Building Trends-Business Benefits Driving New and Retrofit Market Opportunities in Over 60 Countries. Bedford (US): McGraw-Hill Construction Research \& Analytics; 2013.

56. Rashid AFA, Yusoff S. A review of life cycle assessment method for building industry. Renew Sustain Energy Rev. 2015;45:244-8. 
57. Reith A, Orova M. Do green neighbourhood ratings cover sustainability? Ecol Indic. 2015;48:660-72.

58. Feria M, Amado M. Architectural Design: Sustainability in the DecisionMaking Process. Buildings. 2019;9(5):135.

59. Fischer M, Adams H. Engineering-Based Decisions in Construction. J Constr Eng Manag. 2011;137(10):751-4.

60. Cucuzzella C. The normative turn in environmental architecture. J Clean Prod. 2019;219:552-65.

61. Cucuzzella C. When the Narrative of Environmental Certifications Replaces the Debate on Quality. In: Faire des histoires? Du récit d'urbanisme à l'urbanisme fictionnel: faire la ville à l'heure de la société du spectacle. Geneve (Switerland): Fondation Braillard Architectes; 2015. p. 43-7.

62. Næss P. Normative planning theory and sustainable development. Scand Hous Plan Res. 1994;11(3):145-67.

63. Goubran S, Masson T, Caycedo M. Evolutions in Sustainability and Sustainable Real Estate. In: Walker T, Krosinsky C, Hasan LN, Kibsey SD, editors. Sustainable Real Estate. Cham (Switzerland): Palgrave Macmillan, 2019; p. 11-31.

64. Lützkendorf T, Lorenz DP. Using an integrated performance approach in building assessment tools. Build Res Inf. 2006;34(4):334-56.

65. De Jong M, Joss S, Schraven D, Zhan C, Weijnen M. Sustainable-smart-resilientlow carbon-eco-knowledge cities; Making sense of a multitude of concepts promoting sustainable urbanization. J Clean Prod. 2015;109:25-38.

66. Bayulken B, Huisingh D. A literature review of historical trends and emerging theoretical approaches for developing sustainable cities (part 1). J Clean Prod. 2015;109:11-24.

67. Ahvenniemi H, Huovila A, Pinto-Seppä I, Airaksinen M. What are the differences between sustainable and smart cities? Cities. 2017;60:234-45.

68. Moyer JD, Bohl DK. Alternative pathways to human development: Assessing trade-offs and synergies in achieving the Sustainable Development Goals. Futures. 2019;105:199-210.

69. Le Blanc D. Towards integration at last? The sustainable development goals as a network of targets. New York (US): UN-DESA; 2015. Report No.: ST/ESA/2015/DWP/141.

70. Salvia AL, Leal Filho W, Brandli LL, Griebeler JS. Assessing research trends related to Sustainable Development Goals: local and global issues. J Clean Prod. 2019;208:841-9.

71. Nilsson M, Chisholm E, Griggs D, Howden-Chapman P, McCollum D, Messerli $\mathrm{P}$, et al. Mapping interactions between the sustainable development goals: lessons learned and ways forward. Sustain Sci. 2018;13(6):1489-503.

72. Lafortune G, Fuller G, Moreno J, Schmidt-Traub G, Kroll C. SDG Index and Dashboards_Detailed Methodological paper. New York (US): Bertelsmann Stiftung and Sustainable Development Solutions Network (SDSN); 2018.

73. Allen C, Metternicht G, Wiedmann T. Prioritising SDG targets: assessing baselines, gaps and interlinkages. Sustain Sci. 2019;14(2):421-38. 
74. Lior N, Radovanović M, Filipović S. Comparing sustainable development measurement based on different priorities: sustainable development goals, economics, and human well-being-Southeast Europe case. Sustain Sci. 2018;13(4):973-1000.

75. Santika WG, Anisuzzaman M, Bahri PA, Shafiullah GM, Rupf GV, Urmee T. From goals to joules: A quantitative approach of interlinkages between energy and the Sustainable Development Goals. Energy Res Soc Sci. 2019;50:201-14.

76. Caldés N, Rodriguez-Serrano I. Potential contribution of concentrated solar power in meeting the sustainable development goals. AIP Conf Proc. 2018;2033:120001.

77. Di Foggia G. Energy efficiency measures in buildings for achieving sustainable development goals. Heliyon. 2018;4(11):e00953.

78. von Geibler J, Piwowar J, Greven A. The SDG-Check: Guiding Open Innovation towards Sustainable Development Goals. Technol Innov Manag Rev. 2019;9(3):20-37.

79. Wen L, Hiyama K. A Review: Simple Tools for Evaluating the Energy Performance in Early Design Stages. Procedia Eng. 2016;146:32-9.

80. Kanters J, Horvat M. The design process known as IDP: A discussion. Energy Procedia. 2012;30:1153-62.

81. Guy S, Moore SA. Sustainable Architecture and the Pluralist Imagination. J Archit Educ. 2007;60(4):15-23.

82. Guy S, Framer G. Contested Constructions: The competing logics of green buildings and ethics. In: Fox W, editor. Ethics and The Built Environment. London (UK): Routledge; 2000. p. 73-87.

83. Cucuzzella C, Goubran S. Infrastructure as a Deeply Integrated Sustainable Urban Project. J Sustain Res. 2019;1:e190005.

84. Hansen HTR, Knudstrup M-A. The Integrated Design Process (IDP): a more holistic approach to sustainable architecture. In: Action for sustainability: The 2005 World Sustainable Building Conference; 2005 Sep 27-29; Tokyo, Japan. Tokyo (Japan): Tokyo National Conference Board; 2005. p. 894-901.

85. Chansomsak S, Vale B. Can Architecture Really Educate People For Sustainability. In: Proceedings of the 2008 World Sustainable Building Conference (SB08); 2018 Sep 21-25; World SB08 Convention Centre. Melbourne (Australia): ASN Events Pty Ltd; 2008.

86. Cucuzzella C, Hammond CI, Goubran S, Lalonde C, editors. Du Didactisme en Architecture/On Didacticism in Architecture. Montreal (Canada): Potential Architecture Books; 2019.

87. Bhamra TA. Ecodesign: The search for new strategies in product development. J Eng Manuf. 2004;218(5):557-69.

88. Ceschin F, Gaziulusoy I. Evolution of design for sustainability: From product design to design for system innovations and transitions. Des. Stud. 2016;47:118-63.

89. Dewberry E. Ecodesign Strategies. Eco Des. 1995;IV(1):32-3. 
90. Dewberry E. Ecodesign: present attitudes and future directions; studies of UK company and design consultancy practice. Milton Keynes (UK): Open University; 1996.

91. Dewberry E, Goggin P. Spaceship ecodesign. Co-Design Interdiscip J Des Context Stud. 1996;5-6(1-3):12-7.

92. Brezet JC. Ecodesign : a promising approach to sustainable production and consumption. The Hague (Netherlands): Rathenau Institute; 1997.

93. Brezet H. Dynamicsin Ecodesign Practice. Ind Environ. 1997;20(1-2):21-4.

94. Fletcher KT, Goggin PA. The Dominant Stances on Ecodesign: A Critique. Des Issues. 2001;17(3):15-25.

95. Cucuzzella C. Creativity, sustainable design and risk management. J Clean Prod. 2016;135:1548-58.

96. Lehni M; World Business Council for Sustainable Development. Ecoefficiency: creating more value with less impact. Geneva (Switzerland): WBCSD; 2000.

97. Guy S, Farmer G. Reinterpreting Sustainable Architecture: The Place of Technology. J Archit Educ. 2001;54(3):140-8.

98. Orr DW. The Nature of Design: Ecology, Culture, and Human Intention. New York (US): Oxford University Press; 2002.

99. Hajer MA. The Politics of Environmental Discourse. New York (US): Oxford University Press; 1995.

100. Prishtina SM. Language and Ideology in the Context of Language Policy of Albanian Language. J Educ Soc Res. 2018;8(2):125-32.

101. Bovati M. 'There's a certain Slant of light...'. The tools of qualitative forecasting and interpretative synthesis of environmental factors in the field of sustainable architectural and urban design. TECHNE. 2017;13:222-35.

102. Schön AD. The Reflective Practitioner. New York (US): Basic Books; 1983.

103. Cucuzzella C. Judging in a World of Expertise. In: Chupin J-P, Cucuzzella C, Helal B, editors. Architecture Competitions and the Production of Culture, Quality and Knowledge-An International Inquiry. Montreal (Canada): Potential Architecture Books Inc.; 2015. p. 145-61.

104. Nelson HG, Stolterman E. The Design Way: Intentional Change in an Unpredictable World. 2nd ed. Cambridge (US): The MIT Press; 2012.

105. Boutinet J-P. Anthropologie du projet. Paris (France): Quadrige (Presses universitaires de France); 2005. French.

106. Morin E. On Complexity. Cresskill (US): Hampton Press, Inc; 2008.

107. Le Moigne J-L. La Modélisation des Systemes Complexes. Paris (France): Dunod; 1999. French.

108. Morin E, Weinmann H. La Complexité Humaine. Paris (France): Flammarion; 1994. French.

109. Boutinet J-P. Les multiples facettes du projet. Sci Hum. 1993;39:20-4.

110. Boutinet J-P. Psychologie des conduites à projet. Paris (France): Presses universitaires de France; 2014. French.

111. Fry T. Design futuring: sustainability, ethics, and new practice. Oxford (UK): Berg; 2009. 
112. Fisher T. Architectural design and ethics: tools for survival. Amsterdam (Netherlands): Architectural Press; 2008.

113. Lynch AJ, Mosbah SM. Improving local measures of sustainability: A study of built-environment indicators in the United States. Cities. 2017;60:301-13.

114. USGB Council. LEED v4 Building Design and Construction. Washington (US): USGBC; 2014.

115. Marshall-Baker A. Design Futuring: Sustainability, Ethics and New Practice, by Tony Fry. Interiors. 2011;2(1):138-40.

116. Lévy J, Kitchen R, Ingold T. A cartographic turn : mapping and the spatial challenge in social sciences. Lausanne (Switzerland): EPFL Press; 2015.

117. The Oslo Manifesto: Design and Architecture for the SDGs. The Oslo Manifesto, 2015. Available from: http://oslomanifesto.org/. Accessed 2018 Sep 6.

118. Institute of Architecture and Technology (KADK); The Danish Association of Architects; The UIA Commission on the UN Sustainable Development Goals. An architecture guide to the UN 17 Sustainable Development Goals. Copenhagen (Denmark): KADK; 2018.

119. Yudelson J. The eco-charrette. In: Green Building Through Integrated Design. New York (US): McGraw-Hill Professional Publishing; 2008. p. 67-80.

120. Mozuni M, Jonas W. An Introduction to the Morphological Delphi Method for Design: A Tool for Future-Oriented Design Research. She Ji J Des Econ Innov. 2017;3(4):303-18.

121. Yudelson J. The Practice of Integrated Design. In: Green Building Through Integrated Design. New York (US): McGraw-Hill Professional Publishing; 2008. p. 45-66.

122. Lauckner H, Paterson M, Krupa T. Using Constructivist Case Study Methodology to Understand Community Development Processes: Proposed Methodological Questions to Guide the Research Process. Qual Rep. 2012;17(13):1-22.

123. Neuman WL, Robson K. Basics of Social Research: Qualitative and Quantitative Approaches. 1st ed. Toronto (Canada): Pearson Education Inc.; 2004.

124. Athienitis A, O'Brien W, editors. Modeling, Design, and Optimization of NetZero Energy Buildings. Montreal (Canada): Wiley; 2015.

125. Czerwinska D. Green building: Improving the lives of billions by helping to achieve the UN Sustainable Development Goal. Green building \& the Sustainable Development Goals. 2017. Available from: https://www.worldgbc.org/news-media/green-building-improving-livesbillions-helping-achieve-un-sustainable-development-goals. Accessed 2019 Jun 3.

126. Wackernagel M, Hanscom L, Lin D. Making the Sustainable Development Goals Consistent with Sustainability. Front Energy Res. 2017;5:1-5.

127. Touloupaki E, Theodosiou T. Optimization of Building form to Minimize Energy Consumption through Parametric Modelling. Procedia Environ Sci. 2017;38:509-14. 
128. Maes MJA, Jones KE, Toledano MB, Milligan B. Mapping synergies and tradeoffs between urban ecosystems and the sustainable development goals. Environ Sci Policy. 2019;93:181-8.

129. Nunes AR, Lee K, O’Riordan T. The importance of an integrating framework for achieving the Sustainable Development Goals: The example of health and well-being. BMJ Glob Health. 2016;1(3):e000068.

130. Rönn M, Kazemian R, Andersson JE. The architectural competition : research inquiries and experiences. Stockholm (Sweden): Axl Books; 2011.

131. Strebel I, Silberberger J, editors. Architecture competition. Project Design and the Building Process. Basingstoke (UK): Taylor \& Francis Ltd; 2017.

132. Chupin J-P, Cucuzzella C, Helal B, editors. Architecture competitions and the production of culture, quality and knowledge: an international inquiry. Montreal (Canada): Potential Architecture Books; 2015.

How to cite this article:

Goubran S, Cucuzzella C. Integrating the Sustainable Development Goals in Building Projects. J Sustain Res.

2019;1:e190010. https://doi.org/10.20900/jsr20190010 